\title{
How the land system with Chinese characteristics affects China's economic growth - an analysis based on a multisector dynamic general equilibrium framework
}

\author{
Kai Liu \\ Renmin University of China, Beijing, China
}

Land system and economic growth

\begin{abstract}
Purpose - What is the relation between the land system with Chinese characteristics and the country's highspeed economic growth in the past decades? There is a lack of rigorous academic research based on the general equilibrium theory of macroeconomics on this issue.

Design/methodology/approach - By building a multisector dynamic general equilibrium framework with land system, this paper explores how the land supply mode with Chinese characteristics affects China's economic growth as well as its transmission mechanism.

Findings - This paper confirms the importance of land system with Chinese characteristics in explaining the mystery of China's high-speed economic growth. Counterfactual analysis shows that if China adopts a land system similar to that of other developing countries, GDP will drop 36\% from the current level under the baseline model.

Originality/value - As the industrial sector shrinks relatively and the output elasticity of infrastructure decreases, this inhibitory effect will become more apparent. China should improve its land supply mode, especially expand the supply of commercial and residential land and reduce the cost of land in the service sector. This can promote better economic development in the future and thus improve household welfare and the structure of aggregate demand, replace "land-based public finance" and thus inhibit the "high leverage" risks of local governments.
\end{abstract}

Keywords Land system, Economic growth, Infrastructure, Land-based public finance

Paper type Research paper

\section{JEL Classification - H27 H41 O41 O43 P26}

(C) China's Industrial Economics. Published in China Political Economy. Published by Emerald Publishing Limited. This article is published under the Creative Commons Attribution (CC BY 4.0) licence. Anyone may reproduce, distribute, translate and create derivative works of this article (for both commercial and non-commercial purposes), subject to full attribution to the original publication and authors. The full terms of this licence may be seen at http://creativecommons.org/licences/by/4.0/ legalcode. Originally published in Simplified Chinese in China Industrial Economics.

The author would like to thank anonymous review experts and the editorial department for their valuable feedbacks; as well as to show his appreciation for the valuable insights provided by Professor JIA Junxue, Professor LV Bingyang, Professor LU Ming, Professor PAN Min, Associate Researcher CHEN Xiaoliang, Associate Professor Li Rong and the participants at the 2017 Macroeconomics National Forum, the China Finance Forum, the Finance and Taxation Forum of the School of Finance of Renmin University of China, the Seminar on Growth and Fluctuation of Shanghai Jiao Tong University, the first China Urban Economists Forum, and the Seminar on "Structural deleveraging and High-Quality Development". The author is also thankful for the research assistance provided by YUE Zihang and WANG Duzhou. The author bears all the responsibility for this paper.

Funding: The project is funded by Renmin University of China's Major Planning Project "World Economy from a Long-term Perspective: Current Situation and Future Trends" (Approval No. 17XNLG05).

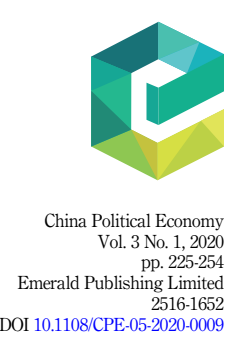

DOI 10.1108/CPE-05-2020-0009 
CPE

3,1

\section{Introduction}

Land is an important factor of production. Effective supply of land is essential for the development of manufacturing industry and service industries such as real estate, catering and storage, and financial services. This is especially true for some developing countries with high population density and relatively scarce land (Deininger, 2003). Realizing industrialization is a top development task for developing countries, and infrastructure construction is particularly important for industrialization and economic development. However, both industrial sector development and infrastructure construction require a large amount of land. Therefore, the land system that determines the allocation of land is the basic economic system that affects a country's economic growth [1].

It is of great theoretical significance and provides important policy guidance to study the land system with Chinese characteristics and the relation between China's land supply mode and its economic growth. Since the reform and opening up, China's economy has continued to grow rapidly for 40 years, becoming the world's second largest economy in nominal terms and the world's largest economy on PPP basis. As a successful case of a developing country, China's rapid economic growth has not only profoundly changed the world economic landscape and international political pattern but also intrigued economists to look into China's economic growth and enrich the theory of economic growth. A rigorous theoretical model and a macro-level study of the relation between the land system with Chinese characteristics and the high economic growth in the past few decades will solve the mystery of China's economic growth with a new theoretical perspective [2]. In addition, the land supply model with Chinese characteristics is closely related to the problems of high leverage and debt risks of local governments, insufficient housing supply in first and second tier cities and household welfare distortion. How should the future land supply model and related policies be adjusted to promote better and higher quality development of China's economy? This article will try to discuss the above important issues by constructing and analyzing a quantitative macro-model including the factor of the land system.

There is a serious deficiency in existing literature about the relation between the land system, the land supply mode and China's overall economic growth. A large number of studies focused on the "land-based public finance" behavior of local governments and its effect on local economic development and urbanization (Zhang et al., 2011; China's Economic Growth Frontier Research Group, 2011; Sun and Zhou, 2013; Lei and Gong, 2014; Wu et al., 2015; Fu et al., 2017; Xu et al., 2018). Most of these studies used provincial or municipal panel data to study the impact of land system with Chinese characteristics on regional economic development from an empirical perspective. However, due to the limitations of empirical econometric models, these studies cannot be used to analyze the effect of land system factors on China's overall economic growth, nor can they scientifically depict the specific transmission mechanism of land system factors at the general equilibrium level. In addition, an extensive literature has been developed on China's economic growth from multiple perspectives, such as the perspective of factor accumulation based on Solow growth model (Liang and Dong, 2015; Zhang et al., 2007), the perspective of total factor productivity (TFP) improvement (including technological progress and resource allocation efficiency improvement) (Kang et al., 2007; Song et al., 2009; Lee and Malin, 2013), the demographic perspective (Liao, 2013; Guo et al., 2013), the perspective of government competition in the context of central-local relations (Fu and Qiao, 2011), the perspective of informal system (Jia and Guo, 2011), etc. However, among these studies, there is a lack of in-depth research on how does the land system with Chinese characteristics, which is significantly different from that of other developing countries, affect China's economic growth.

This paper will discuss in detail the relation between China's land system, land supply mode and its economic growth by constructing a multisector dynamic general equilibrium analysis framework. In view of the important role of the factor of land in the industrial sector, 
real estate and other service sectors and infrastructure construction, the model in this paper will include the aforementioned multiple sectors such as industrial and service sectors, and land and infrastructure will be viewed as production factors in the production function of each sector. Existing literature on how "land-based public finance" or "land-based public finance" affects macroeconomic fluctuations through real estate market and other channels based on a multisector dynamic stochastic general equilibrium (DSGE) (e.g. Guo et al., 2015; Zhao et al., 2017; Mei et al., 2018) provided useful reference for the construction of dynamic growth model in this paper. However, it should be noted that these studies generally do not distinguish industrial land from commercial and residential land and their different pricing mechanisms. Also, they do not fully describe the entire nonagricultural land market and the composition of GDP products, and their focus is on the economic fluctuations rather than growth.

The conclusions of this paper are as follows: first, in terms of economic growth, compared with the nonpublic land ownership system, the public land ownership system brings China an institutional advantage, which is an important reason for China's rapid economic growth in the past few decades. Second, under the basic system of public land ownership, the current land policy is not optimal, and further improvement is needed to promote better economic development and household welfare. Third, the key to improving the land supply mode is to expand the supply of commercial and residential land and reduce the cost of land in the service sector (especially in a few first-and second-tier cities), which can promote high-quality development in many ways.

Compared with the existing research, the main innovation of this paper lies in two points. First, the land ownership system is incorporated into the economic growth model, and the impact of land system on economic growth is studied under the condition that both land and infrastructure are important factors of production, which has been rarely studied in the existing literature on economic growth. Second, this paper has systematically and quantitatively studied how land system affects China's economic growth, and highlighted the importance of land system with Chinese characteristics in solving the mystery of China's economic growth. Numerical simulation analysis based on quantitative macro model in this paper has also provided useful suggestions for improving the land supply model. Although the relation between the land system with Chinese characteristics and China's economic growth has been discussed in newspapers, magazines and other academic journals, there are few rigorous academic articles based on the general equilibrium framework of macroeconomics. The research in this paper has filled in the gap in relevant literature.

The rest of this paper is structured as follows: the second part provides a number of typical facts, based on which we make some reasonable assumptions to build the model; the third part is the baseline model. The fourth part analyzes the relation between the land system and China's economic growth, focusing on comparing China's economic growth under the nonpublic land ownership system and the public land ownership system, discusses the optimal land policy and the significance of the adjustment of land supply mode for future economic development, and tests its soundness. In the fifth part, we summarize the full text and put forward our policy suggestions.

\section{Typical facts}

2.1 China's land system has distinct Chinese characteristics and is markedly different from other countries in terms of land ownership and land development rights

Land system is the sum of a series of systems, laws and regulations related to land ownership, possession, development, use and income. China's public land ownership system consists of state land ownership and collective land ownership. Urban land belongs to the state, and rural and suburban land belongs to rural residents collectively, except for the land owned by 
CPE 3,1

the state as stipulated by law. This is different from most other countries in the world. Countries (such as France) that have undergone relatively thorough bourgeois revolutionary land reforms, and those (such as India) that have not undergone such revolutions, as well as those with a colonial history (such as the United States), they mostly have a private land ownership system $(\mathrm{He}, 2017)$ [3]. Take India for instance: $70 \%$ of India's land is privately owned and basically has permanent property rights (Yao and Liu, 2015). Another example is the Great Britain, although the Monarch owns the superior interest in all land from a legal perspective, the perpetual freeholder is the actual owner of land.

In terms of the right to land development, the Chinese government has a stronger hold than the governments of other economies. Although nonpublic land ownership countries (such as the United States and France) have also adopted land control measures to restrict private land rights (Ma, 2013), their capabilities are incomparable with those of the Chinese government. Moreover, in urban development, Britain, the United States, France and some other countries are required to purchase a certain amount of private land development rights using funds mainly from the public sector, which usually causes high financial burden.

In the aspect of land requisition, compared with other economies, Chinese governments have a comparatively low cost to acquire land resources and a relatively high land income. After the reform and opening up, especially after 1992, the paid land use system has been gradually established. The system of paid transfer of the right to use the state-owned urban land in cities and towns enables local governments to obtain a large amount of income and guide economic development by controlling the land market. On the one hand, urban land is owned by the state (which incurs zero cost to the government), and local governments have sufficient land to allocate and lease. On the other hand, the combination of collective ownership of suburban and rural land and expropriation of collective land granted local governments powerful means to supplement or increase urban state-owned land (Ge and Cen, 2017). Moreover, China implements a strict land use conversion system to ensure absolute dominance in and relatively low cost of land requisition. However, for most countries and regions in the world, land requisition is mostly compensated according to or based on the market price (Chen, 2004), and the cost of acquiring land resources is relatively high.

\subsection{The government divides nonagricultural land into two markets: industrial land and commercial and residential land and adopts different pricing mechanisms}

With the gradual establishment of the paid use of land system, China's nonagricultural land is divided into two markets: industrial land and commercial and residential land (including land for tertiary uses and urban residential land). Among them, industrial land is provided at a low price and in sufficient supply, while the pricing of commercial and residential land is gradually determined by the market, and the income from the transfer of commercial and residential land use right has become an important source of local government revenue (Zhao et al., 2017). Land development costs includes land requisition and relocation compensation, subsidies to relocated farmers and early development costs for land transfer. Local governments generally offer land to industrial enterprises at a price only slightly higher than the cost of land development, and sometimes at a price lower than the cost or even for free to attract and retain successful enterprises (Jiang et al., 2007). For commercial and real estate land, the local government will sell it via market-oriented methods such as bidding, auction and listing, in order to obtain maximum high rent for government revenue. Based on the land transaction data between listed companies and local governments, we discovered the evolving trend of the average price of industrial land and commercial and residential land: generally speaking, from 2010 to 2015 , the nominal industrial land price increased slowly, while the price difference between industrial land and commercial and residential land was widened over time. 
The differentiated pricing mechanism in the land market resulted from the motivation of local governments to grow economy, especially industrial economy, and the so-called "landbased public finance". In the past few decades, China has been in the stage of rapid development of industrialization, therefore Chinese industry is the backbone of its economy. Local governments, as land monopoly operators, provided land at low prices to promote industrial development, and as a result greatly enhanced local economic growth (China's Economic Growth Frontier Research Group, 2011). However, the reform of the revenuesharing system in 1994 and the 1998 housing reform have gradually formed the "land-based public finance". Local governments have increased their revenue by selling commercial and residential land at high prices. According to the data of the Ministry of Finance of the People's Republic of China, the average share of land transfer income in GDP from 2011 to 2015 was about $6.1 \%$.

Based on the above facts, we will make the following assumptions in the baseline model: land is an important factor of production for both industrial and nonindustrial sectors; the public land ownership system is reflected in the fact that land are owned by the government and land rental income is controlled by the government. The government sets a price for industrial land and nonindustrial land separately, adequately supplies industrial land at a lower price, and raises the price of nonindustrial land by controlling its supply so as to maximize the rental income. In fact, in the later model, we define the production sector according to the divided land markets, the sector that obtains land at low prices is called the "industrial sector", and the sector that purchases land at high prices is called the "commercial sector".

\subsection{The proportion of infrastructure investment in GDP in China has always been at a high level, which is closely related to the public land ownership system}

There is no doubt about the importance of infrastructure for the long-term economic growth of an economy, especially for developing countries (World Bank, 1994, 2006). The definition of infrastructure discussed in this paper is consistent with that of Jin (2012). Fernald (1999), Calderón and Servén (2004) and other scholar's research results all supported that infrastructure can significantly promote economic growth. Agenor (2010) proved through theoretical models that the increase of government investment in infrastructure can help the economy shift from a low-growth equilibrium to a high-growth equilibrium.

The proportion of infrastructure investment in GDP in China has always been at a high level. Infrastructure investment has greatly promoted China's economic growth. The World Bank (2006) suggested in the 1994 World Development Report that the investment in economic infrastructure should not be less than 5\% of GDP. Jin (2012) estimated that China's infrastructure investment accounted for an average of 9.0\% of GDP from 1993 to 2008. Since 2008 , the scale of infrastructure investment in China has remained at a high level, especially since the New Normal of the economy, the proportion of infrastructure investment in GDP is still on the rise.

The rapid development of China's infrastructure investment is inseparable from the public land ownership system. On the one hand, infrastructure construction itself requires a large amount of land, and the public land ownership system ensures the supply of land at a low price for infrastructure construction, greatly reducing the cost of infrastructure construction. On the other hand, a large amount of land transfer income for local governments has become an important source of capital for infrastructure investment. It is estimated that only $15-20 \%$ of the use right of urban land is transferred for commercial, real estate and other for-profit purposes through "bidding, auction and listing". The vast majority of urban infrastructure land is supplied through administrative allocation or at low prices (Jiang et al., 2007). For example, in 2010, China allocated 138,000 ha of land for infrastructure, accounting 
CPE 3,1 for about $28 \%$ of the total supply of state-owned construction land in that year. Under the nonpublic land ownership system, the value of the abovementioned land was valued at around 1.3t $n$ yuan (calculated by the average selling price of $9.35 \mathrm{~m}$ yuan/hectare in the same year), equivalent to $32 \%$ of the total local government revenue of the same year (Ge and Cen, 2017). The British High Speed 2 was approved to start construction in 2017, and its cost was estimated to be quite high [4], with a large part of it being the cost of land. Empirical research shows that "land-based public finance" has increased the financial capacity of local governments and the enthusiasm for economic development, encouraging them to increase investment in infrastructure (Du et al., 2009; Zhao et al., 2017; Medong Prefecture, etc., 2018). According to the data of "National Land Transfer Revenue and Expenditure" released by the Ministry of Finance, more than $50 \%$ of the disposable land transfer revenue of local governments in 2014 and 2015 was used for urban construction, and the land transfer revenue became an important source of funds for infrastructure construction. The public land ownership system contributed a lot to China's sound infrastructure today and realized Sun Yat-sen's dream of infrastructure construction depicted in his The International Development of China. Based on the above facts, we assume in the following baseline model that infrastructure is an important factor of production for both industrial and nonindustrial sectors and infrastructure investment is funded by the government.

\section{Baseline model}

\subsection{The basic settings of the model}

To simplify the model and focus on the analyzing the relation between the land system and the economic growth, we need to abstract the model. Therefore, with reference to existing literature (Zhao et al., 2017; Mei et al., 2018)'s model setting, this paper makes the following assumptions: we do not consider international trade and view China's economy as a closed economy; we will not consider the labor market, and the factors of production include only the material capital $K_{P, t}$ invested and purchased by enterprises, the infrastructure $K_{I, t}$ invested and built by the government, and the land $L_{t}$. We will not distinguish between state-owned enterprises and private enterprises; we will not consider the agricultural sector; to be in line with China's land policy, this paper divides the economy into the "industrial sector" (including part of the production of infrastructure in reality) and the "commercial sector" (including the real estate industry in reality). The two sectors produce intermediate products: $Y_{t}^{1}$ and $Y_{t}^{2}$, namely, "industrial products" and "commercial products". The two intermediate products are made into the final product $Y_{t}(\mathrm{GDP})$ for resident consumption $C_{t}$, enterprises' investment $I_{P, t}$ in physical capital, government investment in infrastructure $I_{I, t}$ and government purchase $G_{t}$.

Different from Zhao et al. (2017) and Mei et al. (2018), which dismissed commercial land in their model construction, this paper fully considers commercial land and views commercial and residential land markets as a whole based on typical facts. The "commercial sector" that uses commercial and residential land to not only produce housing for residents but also commercial buildings and other service products, which can be seen as a simplification of the service industry. Such consideration enables the model to better mirror the reality, and also to calibrate model parameters to better match the macroeconomic data.

In this paper's growth model, land system will affect resources allocation and thus the level of total output in the steady state. This paper assumes that TFP growth rate is 0 , so as to focus on the analysis of the impact of land ownership on the level of GDP in the steady state. The public land ownership system is reflected in the fact that land, as a factor of production, is owned by the government. Land rental income is merged into government income and controlled by the government. In order to mirror the reality, we assume in the baseline model 
that the government controls the rental price of "industrial land" $P_{L, t}^{1}$ for "industrial sector" and sets it at a lower level to promote the development of "industrial sector". The government controls the supply of "commercial land" $L_{t}^{2}$ for the "commercial sector" and its price is determined by market demand. Land rental income is an important source of funds for government infrastructure investment. Figure 1 shows the basic structure of the economy in the baseline model.

\subsection{Production of final products}

The final product $Y_{t}$ are made from intermediate products $Y_{t}^{1}$ and $Y_{t}^{2}$ by the final product manufacturers, and their production function is a CES function (constant elasticity of substitution):

$$
Y_{t}=\left[(1-\rho)^{\frac{1}{\omega}} \cdot\left(Y_{t}^{1}\right)^{\frac{\omega-1}{\omega}}+(\rho)^{\frac{1}{\omega}} \cdot\left(Y_{t}^{2}\right)^{\frac{\omega-1}{\omega}}\right]^{\frac{\omega}{\omega-1}}
$$

$\rho$ reflects the proportion of "commercial goods" in the total demand and $\omega$ is the elasticity of substitution of two intermediate products.

The price of the final product is standardized as 1 , and the market prices of intermediate products $Y_{t}^{1}$ and $Y_{t}^{2}$ are $P_{t}^{1}$ and $P_{t}^{2}$, respectively, assuming that the final product manufacturer is the market price taker. Given the prices of various products, to solve the profit maximization problem, the first order conditions for this problem are

$$
\left\{\begin{array}{l}
Y_{t}^{1}=(1-\rho) \cdot\left(P_{t}^{1}\right)^{-\omega} \cdot Y_{t} \\
Y_{t}^{2}=\rho \cdot\left(P_{t}^{2}\right)^{-\omega} \cdot Y_{t}
\end{array}\right.
$$

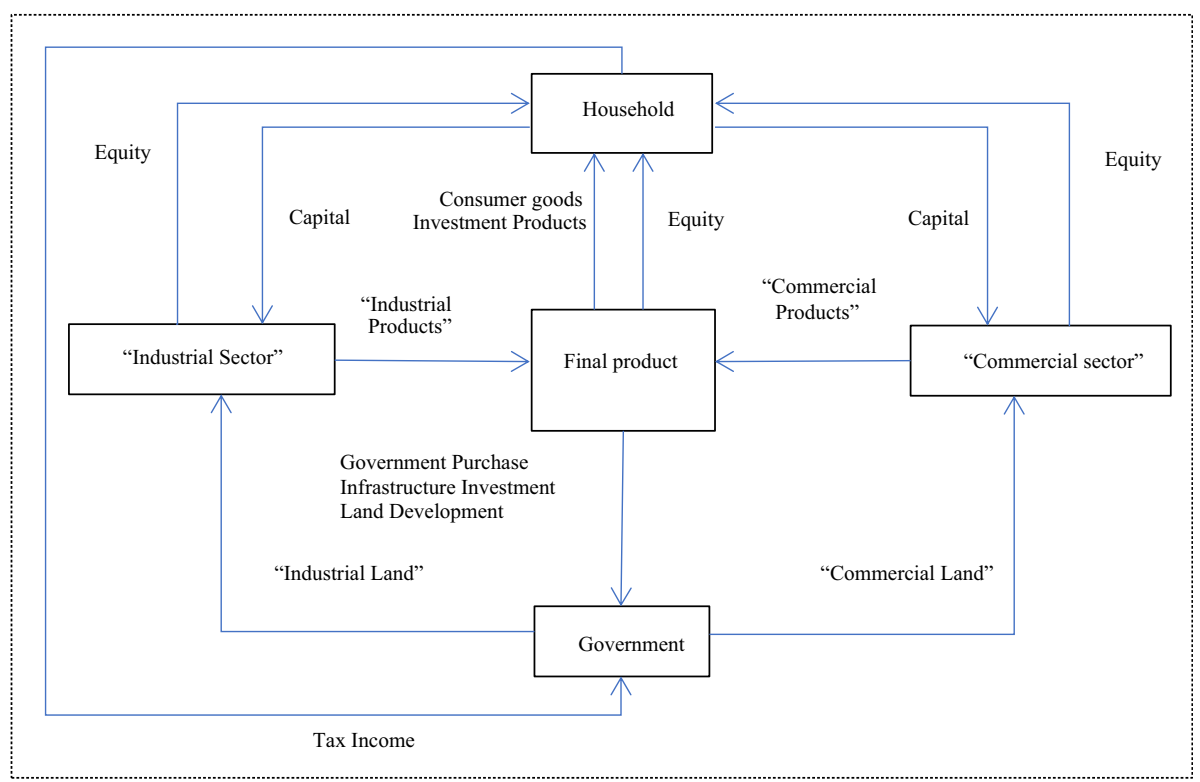

Land system and economic growth . 
CPE 3,1

3.3 Production and pricing of the "industrial sector", "commercial sector" and intermediate products

Assume that the production functions of the representative manufacturers of "industrial sector" (sector 1) and "commercial sector" (sector 2) are as follows [5]:

$$
\left\{\begin{array}{l}
Y_{t}^{1}=A^{1} \cdot\left(K_{I, t}\right)^{\alpha_{1}} \cdot\left\{\left[\left(1-\rho_{1}\right)^{\frac{1}{\omega_{1}}} \cdot\left(K_{P, t}^{1}\right)^{\frac{\omega_{1}-1}{\omega_{1}}}+\left(\rho_{1}\right)^{\frac{1}{\omega_{1}}} \cdot\left(L_{t}^{1}\right)^{\frac{\omega_{1}-1}{\omega_{1}}}\right]^{\frac{\omega_{1}}{\omega_{1}-1}}\right\}^{\beta_{1}} \\
Y_{t}^{2}=A^{2} \cdot\left(K_{I, t}\right)^{\alpha_{2}} \cdot\left\{\left[\left(1-\rho_{2}\right)^{\frac{1}{\omega_{2}}} \cdot\left(K_{P, t}^{2}\right)^{\frac{\omega_{2}-1}{\omega_{2}}}+\left(\rho_{2}\right)^{\frac{1}{\omega_{2}}} \cdot\left(L_{t}^{2}\right)^{\frac{\omega_{2}-1}{\omega_{2}}}\right]^{\frac{\omega_{2}}{\omega_{2}-1}}\right\}^{\beta_{2}}
\end{array}\right.
$$

Where $A^{i}(i=1$ or 2 ) represents the TFP of the sector $i$, and its production factors include infrastructure capital stock $K_{I, t}$, enterprise capital stock $K_{P, t}^{i}$ and land $L_{t}^{i}$. Parameters $\alpha_{i}, \omega_{i}$ and $\beta_{i}$ represent the corresponding elasticity. $\rho_{i}$ represents the relative weight of land, as a production factor, in the production process among the production factors purchased by the enterprise. The structural parameters (such as $\rho_{i}$ ) and related elasticity of the two sectors can be different.

Given the rent $P_{L, t}^{1}$ of "industrial land" and the rent rate $r_{t}$ of enterprise capital, the firstorder conditions to solve the cost minimization problem of representative enterprises of the "industrial sector" are as follows:

$$
\left\{\begin{array}{c}
\frac{L_{t}^{1}}{K_{P, t}^{1}}=\frac{\rho_{1} \cdot\left(P_{L, t}^{1}\right)^{-\omega_{1}}}{\left(1-\rho_{1}\right) \cdot\left(r_{t}\right)^{-\omega_{1}}} \\
m c_{t}^{1}=\frac{\left(1-\rho_{1}\right) \cdot\left(r_{t}\right)^{1-\omega_{1}}}{A^{1} \cdot\left(K_{I, t}\right)^{\alpha_{1}} \cdot \beta_{1} \cdot\left[\frac{L_{t}^{1}}{\rho_{1} \cdot\left(P_{L, t}^{L}\right)^{-\omega_{1}}}\right]^{\beta_{1}-1}}
\end{array}\right.
$$

Where $m c_{t}^{1}$ represents the actual marginal cost of producing a unit of "industrial products".

Similarly, the following first-order conditions apply to the representative enterprise in the "business sector":

$$
\left\{\begin{array}{c}
\frac{L_{t}^{2}}{K_{P, t}^{2}}=\frac{\rho_{2} \cdot\left(P_{L, t}^{2}\right)^{-\omega_{2}}}{\left(1-\rho_{2}\right) \cdot\left(r_{t}\right)^{-\omega_{2}}} \\
m c_{t}^{2}=\frac{\left(1-\rho_{2}\right) \cdot\left(r_{t}\right)^{1-\omega_{2}}}{A^{2} \cdot\left(K_{I, t}\right)^{\alpha_{2}} \cdot \beta_{2} \cdot\left[\frac{L_{t}^{2}}{\rho_{2} \cdot\left(P_{L, t}^{t}\right)^{-\omega_{2}}}\right]^{\beta_{2}-1}}
\end{array}\right.
$$

As mentioned earlier, in the baseline model, the government controls the price of "industrial land" and the supply of "commercial land". Therefore, in an equilibrium state, the following conditions hold: 


$$
\begin{gathered}
P_{L, t}^{1}=P_{L}^{1} \\
L_{t}^{2}=L^{2}
\end{gathered}
$$

$P_{L}^{1}$ and $L^{2}$ are exogenous constants and are set by the government.

Since the final product is only composed of two intermediate products, the intermediate product manufacturers have a certain monopoly power, therefore they have the pricing power over their products. They maximize the profit in by setting the price $P_{t}^{i}(i=1$ or 2$)$ in the following expressions:

$$
\left\{\begin{array}{l}
\pi_{t}^{1} \triangleq P_{t}^{1} \cdot Y_{t}^{1}-r_{t} \cdot K_{P, t}^{1}-P_{L, t}^{1} \cdot L_{t}^{1} \\
\pi_{t}^{2} \triangleq P_{t}^{2} \cdot Y_{t}^{2}-r_{t} \cdot K_{P, t}^{2}-P_{L, t}^{2} \cdot L_{t}^{2}
\end{array}\right.
$$

The profit maximization expressions of intermediate product manufacturers are also constrained by the intermediate product demand function given in Eqn (2). To solve the profit maximization problem under this constraint condition, the following pricing equation can be obtained [6]:

$$
\left\{\begin{array}{l}
P_{t}^{1}=\frac{\omega}{\omega-1} \cdot m c_{t}^{1} \\
P_{t}^{2}=\frac{\omega}{\omega-1} \cdot m c_{t}^{2}
\end{array}\right.
$$

\subsection{The household sector and the government sector}

The utility function and budget constraint conditions of representative households are:

$$
\begin{gathered}
U_{0}=E_{0} \sum_{t=0}^{\infty} \beta^{t} u\left(C_{t}\right) \\
\left(1-\delta_{1}\right) \cdot K_{P, t}+r_{t} \cdot K_{P, t}+\pi_{t}=C_{t}+T_{t}+K_{P, t+1}
\end{gathered}
$$

$K_{P, t}$ is the total capital stock held by the household sector (equal to the sum of the capital stock of the "industrial sector" and the "commercial sector" in an equilibrium state), $\delta_{1}$ is its depreciation rate, $\pi_{t}$ is the sum of the profit generated by the household sector due to holding the shares of intermediate product manufacturers and final product manufacturers, $C_{t}$ is the household consumption, and $T_{t}$ is the tax paid by the household to the government [7].

The representative household can maximize its lifetime utility by choosing the consumption level of each period $C_{t}$. The optimal condition is

$$
u^{\prime}\left(C_{t}\right)=E_{t}\left[u^{\prime}\left(C_{t+1}\right) \cdot \beta \cdot\left(1-\delta_{1}+r_{t+1}\right)\right]
$$

Sources of government revenue include tax revenue $T_{t}$, and income from "industrial land" and "commercial land" concessions, while government expenditure includes government purchase expenditure $G_{t}$, infrastructure investment $I_{I, t}$ and land development costs. We assume that the cost of land development is a linear function of the supply of land: $a \cdot\left(L_{t}^{1}+L_{t}^{2}\right)$ Since the model in this paper is a rational expectation model, the Ricardian Equivalence Theorem applies. In order to simplify the model, it can be assumed that the government budget for each period is balanced. Therefore, the government's budget constraint condition can be expressed as follows:

$$
G_{t}+I_{I, t}=T_{t}+P_{L, t}^{1} \cdot L_{t}^{1}+P_{L, t}^{2} \cdot L_{t}^{2}-a \cdot\left(L_{t}^{1}+L_{t}^{2}\right)
$$


CPE 3,1

\section{4}

As this paper aims to examine the balanced growth path under the steady state, and to simplify the model, the following assumptions can be made for the fiscal rules: the government purchase expenditure is a fixed proportion of GDP, and the government levies a fixed tax rate on capital income and corporate profits, namely:

$$
\begin{gathered}
G_{t}=g \cdot Y_{t} \\
T_{t}=\tau \cdot\left[\left(r_{t}-\delta_{1}\right) \cdot K_{P, t}+\pi_{t}\right]
\end{gathered}
$$

$g$ is the ratio of government purchase expenditure to GDP in the steady state, and $\tau$ is the tax rate. Given the tax income, net income from land concession and purchase expenditure of the government of each period, then government investment in infrastructure can be determined by Eqn (10).

\subsection{Model equilibrium}

Let us consider the functions of profits of various manufacturers $\left(\pi_{t}^{1}, \pi_{t}^{2}, \pi_{t}^{3}\right)$, as well as budgetary constraints of households and government sectors, we have:

$$
Y_{t}=C_{t}+\left(I_{I, t}+I_{P, t}\right)+G_{t}+a \cdot\left(L_{t}^{1}+L_{t}^{2}\right)
$$

$I_{P, t}$ is the total investment of enterprise capital, so the following formula is established:

$$
\left(K_{P, t+1}^{1}+K_{P, t+1}^{2}\right)=\left(1-\delta_{1}\right) \cdot\left(K_{P, t}^{1}+K_{P, t}^{2}\right)+I_{P, t}
$$

We have the following equation for infrastructure capital stock $K_{I, t}$ and infrastructure investment $I_{I, t}$ :

$$
K_{I, t+1}=\left(1-\delta_{2}\right) \cdot K_{I, t}+I_{I, t}
$$

$\delta_{2}$ is the depreciation rate of infrastructure.

Let us consider the budget constraints of the household sector and the government sector and the GDP Eqn (12), we have the tax rules of the government sector under balanced conditions:

$$
T_{t}=\tau \cdot\left[Y_{t}-\left(P_{L, t}^{1} \cdot L_{t}^{1}+P_{L, t}^{2} \cdot L_{t}^{2}\right)-\delta_{1} \cdot\left(K_{P, t}^{1}+K_{P, t}^{2}\right)\right]
$$

\subsection{Parameter calibration}

The parameters of the baseline model can be roughly divided into two categories. The first category can be calibrated by referring to relevant documents or standardized assignment. The second category needs to be calibrated by matching the steady-state value of a certain variable with the actual data or theoretical prediction value. As mentioned above, since 1992, the market economy system and the system of paid use of land right have been gradually established. Therefore, the relevant Chinese macroeconomic data used for calibration in this paper are the annual data from 1992 to 2015.

Table 1 shows the calibration results of the parameters of the baseline model. Without losing generality, the TFP parameters of the "industrial sector" and the "commercial sector" $A^{1}$ and $A^{2}$ are both normalized as 1 , and the relative values of the two sectors in the steady state is realized through calibration of other parameters. The output elasticity parameters $\alpha_{1}$ and $\alpha_{2}$ of the infrastructure in the production function are both set to 0.2 , which is consistent with existing literature. Jin (2012) summed up relevant literature on US economic growth, and believed that the output elasticity of infrastructure should be around 0.2. Jin (2012) pointed out that in the literature on the output elasticity of infrastructure in China, the estimated value 
of elasticity level is usually between 0.2 and 0.7 . In the following parts of this article, we will change the assignment of $\alpha_{1}$ and $\alpha_{2}$ to carry out relevant robustness tests. Literature such as He et al. (2007) and Chen et al. (2012) generally believed that in the course of China's economic growth since the reform and opening up, nonlabor factors of production have a higher rate of return (or output elasticity). In view of this, output elasticity parameters $\beta_{1}$ and $\beta_{2}$ are both set to 0.5 . Therefore, about $50 \%$ of the value created by intermediate product manufacturers in the model is paid to nonlabor factors, and the remaining $50 \%$ is taken as gross profit (in reality, gross profit also includes the labor factor income that dismissed from the abstraction in baseline model). In other words, the profit margin of the representative manufacturer of intermediate products is about $100 \%$, so the substitution elasticity $\omega$ of "industrial products" and "commercial products" is set to 2 according to Eqn (8).

We believe that in the process of "industrial products" production, the factor of land is more important, and its substitutability compared with the factor of capital is also relatively smaller, therefore we set $\rho_{1}=0.4, \omega_{1}=1.2$, and $\rho_{2}=0.3, \omega_{2}=1.5$. In consistence with the mainstream literature, we set the utility discount factor $\beta$ at 0.96 . Regarding the depreciation rate of China's capital and infrastructure, Zhang et al. (2004), Gong and Xie (2004) and Jin (2012) all assumed it was around $10 \%$, therefore, we set both $\delta_{1}$ and $\delta_{2}$ at $10 \%$. Without losing generality, we assume that the marginal development cost of land $a$ is 0.05 , and the government sets the transfer price $P_{L}^{1}$ of "industrial land" at a lower level that is only slightly higher than the development cost (0.06) to promote the development of "industrial sector" [8].

The "industrial products" and "commercial products" in this model are an abstraction of the reality and can be compared to the secondary and tertiary industries in reality. Since the ratio of the added value of China's secondary industry and tertiary industry from 1992 to 2015 is about $3: 2$ on average, parameter $\rho$ is set at 0.4 , so that the ratio of the output value of "industrial sector" and "commercial sector" is also about 3:2 under the steady state of the model. $g$ is set at $14.1 \%$ to match the average of the Chinese government's purchase expenditure from 1992 to 2015 . In the model, the tax rate $\tau$ is directly related to the government's financial capacity and infrastructure investment capacity, so we calibrate $\tau$ 's value by matching the model with the proportion of infrastructure investment in GDP in reality. Jin (2012) believes that China's infrastructure investment accounted for about $13 \%$ of GDP from 2003 to 2009. According to the data of China's infrastructure capital stock estimated by Jin (2012), it can be calculated that the average ratio of China's infrastructure investment to GDP from 1992 to 2008 is about $9 \%$, of which the average ratio from 2003 to 2008 is about $12.6 \%$, which is more consistent with the result of Jin (2012). Since we are looking at China's macro-economy since 1992, we refer to the results of Jin (2012) and set the ratio of infrastructure investment to GDP as $9 \%$ in the steady state of the model, thus the tax rate is assigned as $24 \%$. We assume that the government will control the supply of "commercial land" to maximize the net income from the concession of "commercial land". We will see later that the optimal price for "commercial land" is equivalent to three times the cost

Calibration methods: referring to relevant literatures or assigning standardized values

\begin{tabular}{lllllllllll}
\hline Parameter & $A^{1}$ & $A^{2}$ & $\alpha_{1}$ & $\alpha_{2}$ & $\beta_{1}$ & $\beta_{2}$ & $\omega$ & $\rho_{1}$ & $\rho_{2}$ & $\omega_{1}$ \\
Assignment & 1 & 1 & 0.2 & 0.2 & 0.5 & 0.5 & 2 & 0.4 & 0.3 & 1.2 \\
Parameter & $\omega_{2}$ & $\beta$ & $\delta_{1}$ & $\delta_{2}$ & $a$ & $P_{L}^{1}$ & & & & \\
Assignment & 1.5 & 0.96 & $10 \%$ & $10 \%$ & 0.05 & 0.06 & & &
\end{tabular}

Calibration method: matching model values with data or theoretical prediction

$\begin{array}{lllll}\text { Parameter } & \rho & g & \tau & L^{2}\end{array}$

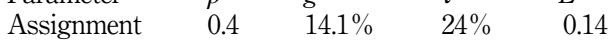

Land system and economic growth

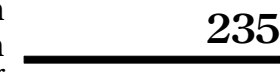


CPE 3,1

\section{6}

Table 2.

Data comparison between first moment and baseline model steady state: data from 1992 to 2015 of land development. Therefore, $L^{2}$ is calibrated to be 0.14 , so that the "commercial land" price under the steady state of the model is equal to three times of the land development cost.

\subsection{Model solution and basic analysis}

Given the initial state of the economy, when all endogenous variables enable Eqns (1)-(15) to hold, the economy is in a general equilibrium state. Since this paper examines China's longterm economic growth, we focus on analyzing the steady state of the model. In the steady state of balanced growth, all endogenous variables (e.g. $\left.Y_{t}, C_{t}, I_{I, t}\right)$ are constants and do not change (they can be expressed by corresponding variables with the time subscript removed, e.g. $Y, C, I_{I}$ ). After the structural parameters of the model are determined (through calibration methods in this paper), the steady-state solution of the baseline model can be obtained by using Equations (1)-(15) and computer numerical calculation.

Table 2 shows the first moment of some macroeconomic data of China from 1992 to 2015 and the corresponding steady-state values of the baseline model. The real interest rate in the data is defined as the benchmark interest rate of one-year loan minus the year-on-year increase in CPI. Since China's inflation rate was very high from 1993 to 1995, the average value of the data is the average value from 1996 to 2015. Through comparison, we find that the baseline model fits some important macro variables well.

\section{Land system and China's economic growth}

4.1 Comparison between the public land ownership and nonpublic land ownership systems: the public land ownership is more conducive to China's economic growth

If China did not adopt the basic economic system of public land ownership and maintained the historical system of private land ownership like many developing countries did, what would China's economic growth be like? Different from the baseline model, this part of the paper assumes that the land is no longer owned by the government but by private individuals (i.e. households). Therefore, the economic structure in Figure 1 will also change, and the land providers (i.e. the receivers of land rent) are not the same, as shown in Figure 2. Based on historical and international experience, the land market under nonpublic ownership system will quickly form a monopoly market through land annexation, and the land will eventually be controlled by a small minority (Niu and Ding, 1990; Xie and Li, 2012; Van der Ploeg et al., 2015; Swinnen et al., 2016).Therefore, without losing generality, we assume that the representative household with land ownership have the pricing power over rent and can differentiate pricing according to the different characteristics of the "industrial land" market and the "commercial land" market.

\begin{tabular}{lcc}
\hline & $\begin{array}{c}\text { Average value } \\
\text { of data }\end{array}$ & $\begin{array}{c}\text { Steady-state values } \\
\text { of the baseline value }\end{array}$ \\
\hline Ratio of added value of secondary industry to tertiary industry & 1.5 & 1.5 \\
Government purchase expenditure's share in GDP & $14.1 \%$ & $14.1 \%$ \\
Investment in infrastructure's share in GDP & $9.0 \%$ & $9.0 \%$ \\
Tax's share in GDP & $16.0 \%$ & $22.0 \%$ \\
Real interest rate & $4.1 \%$ & $4.2 \%$
\end{tabular}

Source(s): National Bureau of Statistics of China, Jin (2012) and the author's calculation. Among them, the "Tax's share in GDP" is defined as the ratio of government tax revenue to GDP plus deficit ratio to match the baseline model where there's no deficit and government debt; the "real interest rate" is defined as the benchmark one-year loan interest rate minus the year-on-year increase in CPI, since China had high inflation rate from 1993 to 1995, so we use the average value from 1996 to 2015 


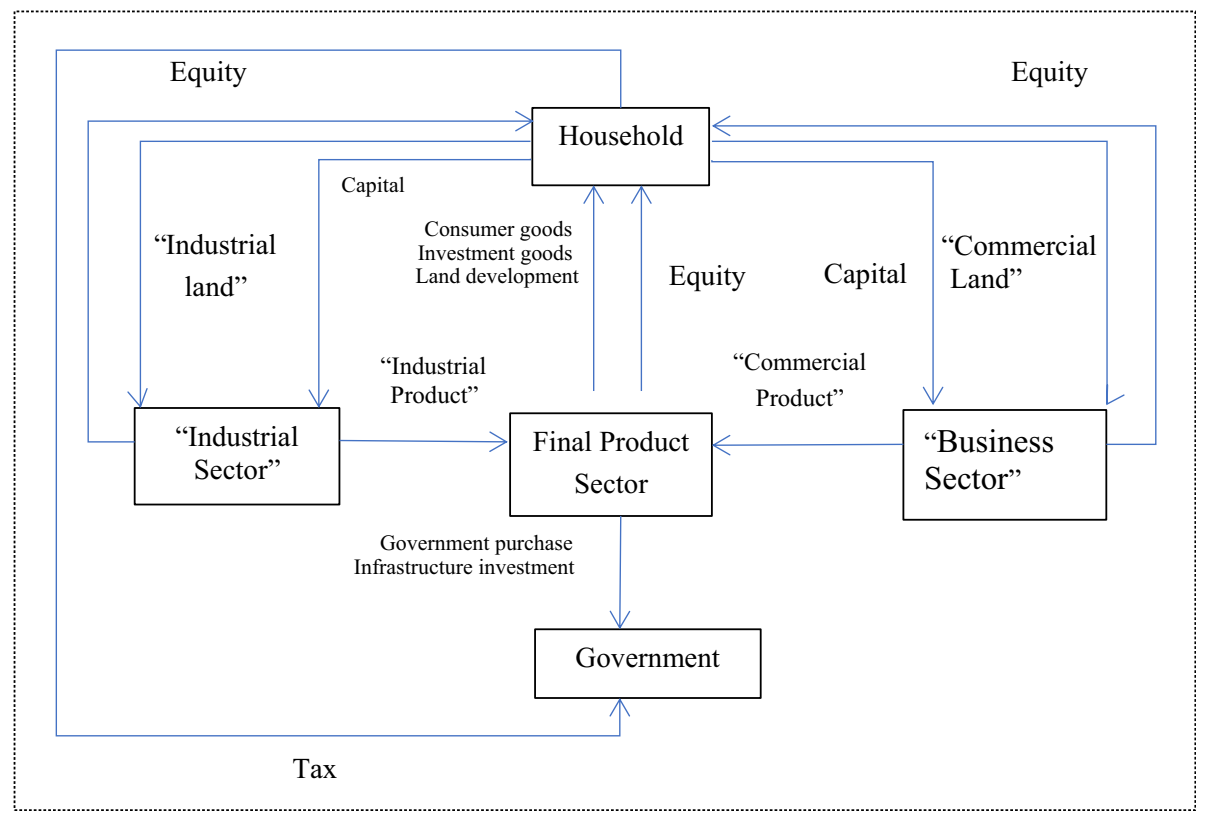

Land system and economic growth

Consider the local equilibrium of the "industrial land" market. The net rent of this land market is $\left(P_{L, t}^{1} \cdot L_{t}^{1}-a \cdot L_{t}^{1}\right)$, according to the first equation of (4), given other conditions unchanged, the demand for "industrial land" $L_{t}^{1}$ is a function of its rent $P_{L, t}^{1}$, and the elasticity of demand is $\omega_{1}$. The representative household maximizes the net rent of the "industrial land" market by setting the rent of the "industrial land" $P_{L, t}^{1}$. Solving this optimization problem and we get the following first-order conditions:

$$
P_{L, t}^{1}=\frac{\omega_{1}}{\omega_{1}-1} \cdot a
$$

Similarly, for the "commercial land" market, the following conditions can be obtained to determine the optimal rent:

$$
P_{L, t}^{2}=\frac{\omega_{2}}{\omega_{2}-1} \cdot a
$$

Under the nonpublic land ownership system, the representative household receives the land rent, so its budget constraint is:

$$
\left(1-\delta_{1}\right) \cdot K_{P, t}+r_{t} \cdot K_{P, t}+\pi_{t}+P_{L, t}^{1} \cdot L_{t}^{1}+P_{L, t}^{2} \cdot L_{t}^{2}-a \cdot\left(L_{t}^{1}+L_{t}^{2}\right)=C_{t}+T_{t}+K_{P, t+1}
$$

Assuming that the government levies taxes on land rent with tax rate $\tau$ [9], then the government's tax Eqn (15), correspondingly becomes:

$$
T_{t}=\tau \cdot\left[Y_{t}-a \cdot\left(L_{t}^{1}+L_{t}^{2}\right)--\delta_{1} \cdot\left(K_{P, t}^{1}+K_{P, t}^{2}\right)\right]
$$

At the same time, the government's budget constraint changes to:

$$
G_{t}+I_{I, t}=T_{t}
$$

The market equilibrium now is determined by Eqns (1)-(5), (8)-(9), (11)-(14) and (16)-(19). 
CPE

3,1

238

Table 3 shows the comparison of results between the steady-state values of major macroeconomic variables under the nonpublic land ownership system and the baseline model under the public land ownership system. With other conditions remain unchanged, under the non-public land ownership system, GDP decreases by $36 \%$, and the output value of the "industrial sector" and the "commercial sector" decrease by 42 and $25 \%$ respectively. Fiscal revenue decreases by $38 \%$, and infrastructure investment and stock capital decrease by 40 and $41 \%$, respectively. The decline in GDP has led to a 34\% drop in household welfare, which is measured by the per capita consumption level in the steady state [10].

The numerical simulation results of the above counterfactual analysis are also consistent with our theoretical predictions. Under the nonpublic land ownership system, the important production factor land is monopolized by the household sector. On the one hand, the "industrial sector" (including the production sector of part of the infrastructure facilities in reality), which occupies a dominant position in the national economy, can no longer purchase land factors at a cheap rental price, which is not conducive to the development of the "industrial sector". In fact, compared with the baseline model under the public land ownership system, the actual marginal cost of "industrial products" under the non-public land ownership system has increased by $6 \%$. For example, the cost of industrial land in India is quite high, which hinders its industrialization process (Yao and Liu, 2015). On the other hand, land rental income is no longer owned by government sectors but by household sectors, which inhibits the government's ability to finance infrastructure construction, thus reducing infrastructure investment and weakening economic growth. At the same time, under the double pressure of rising marginal cost of "industrial products" and declining marginal output under the condition of insufficient infrastructure stock, the household sector with monopoly rent income not only did not increase private investment but also reduced its investment (by 20\%). The rise in marginal costs caused by the rise in land rent, the insufficient investment in infrastructure caused by the limited financing capacity of the government and the insufficient private investment caused by the deterioration of the economic environment have jointly led to the decline in the output value of the "industrial sector" and the "commercial sector" and the sharp decline in GDP. The decline in GDP has also lowered the level of consumption in the household sector, which in turn has led to a sharp decline in social welfare [11].

In this model, there are two core reasons why the public land ownership system is more conducive to economic growth and household welfare than the nonpublic land ownership system. First, land factor tends to form monopoly markets, and monopoly will generally lead to distortion of resource allocation. Under the nonpublic land ownership system, there will be monopolies in the two markets of "industrial land" and "commercial land". Therefore, there will be greater efficiency distortion and welfare distortion than the baseline model of monopoly in the market of "commercial land". Second, infrastructure, as a public good, plays

\begin{tabular}{|c|c|c|c|c|c|c|c|}
\hline Variable & GDP & $\begin{array}{l}\text { Output } \\
\text { value of } \\
\text { the } \\
\text { "industrial } \\
\text { sector" }\end{array}$ & $\begin{array}{l}\text { Output value } \\
\text { of the } \\
\text { "commercial } \\
\text { sector" }\end{array}$ & $\begin{array}{l}\text { Fiscal } \\
\text { revenue }\end{array}$ & $\begin{array}{c}\text { Infrastructure } \\
\text { investment }\end{array}$ & $\begin{array}{l}\text { Infrastructure } \\
\text { capital stock }\end{array}$ & $\begin{array}{l}\text { Resident } \\
\text { Welfare }\end{array}$ \\
\hline $\begin{array}{l}\text { Percentage } \\
\text { decrease } \\
\text { compared } \\
\text { to baseline } \\
\text { model }\end{array}$ & 36 & 42 & 25 & 38 & 40 & 41 & 34 \\
\hline
\end{tabular}

\section{Table 3.}

China's

macroeconomic under the nonpublic land ownership system 
an important role in economic growth. When the land rent goes to the government, the government can use it for infrastructure investment to reduce the marginal cost of production and drive enterprise investment. However, when the land rent goes to the private sector, the private sector will not invest in infrastructure but only care about the private investment income. As a result, the lack of infrastructure leads to an increase in marginal costs, which in turn inhibits private investment [12].

A reasonable conjecture is that under the nonpublic land ownership system, the government can raise taxes or issue bonds to finance infrastructure construction to make up for the shortage of infrastructure investment. In response to this point of view, we conducted another counterfactual analysis: under the nonpublic land ownership system, the government increased tax rates to achieve equal level of GDP as the baseline model under the public land ownership system. Numerical simulation shows that the tax rate needs to be increased to $32.5 \%$ from the previous $24 \%$ in order to produce equivalent GDP to the baseline model under the public land ownership system. The comparison of other macroeconomic variables is shown in Table 4. In this case, the marginal cost increase in the "industrial sector" caused by the increase in land rent has not changed, so although the increase in infrastructure stock has helped, the output value of the "industrial sector" is still $10 \%$ lower than the baseline model. In addition, compared with the baseline model under the public land ownership system, the policy of raising taxes to finance infrastructure construction for growth has lower fiscal efficiency and infrastructure investment efficiency.

Generally speaking, tax is distortionary and raising tax rate may incur certain welfare losses. Therefore, compared with the baseline model, under the nonpublic land ownership system, although increasing tax rate from $24 \%$ to $32.5 \%$ can reach the same level of total output, household welfare declined by $9 \%$. This is also the inevitable result of excessive and inefficient infrastructure investment crowding out resident consumption. Further analysis indicates that under the nonpublic land ownership system, although the policy of increasing tax rate to promote growth can bring about a long-term steady-state GDP increase, its promoting effect on household welfare (per capita consumption level under the steady-state condition) is not linear or monotonous.

That said, comparing Table 3 with Table 4, we find that it is still desirable for the government to raise tax rates to finance infrastructure construction under the nonpublic land ownership system when there is insufficient infrastructure stock capital, as this is conducive to the increase of GDP and the improvement of household welfare in the long run. Therefore, for most developing countries whose basic system of nonpublic land ownership cannot be changed for the time being, using financial means to promote infrastructure investment is the right policy choice when the infrastructure stock capital is insufficient. This is also consistent with the conclusions of the World Bank (2006) and Calderón and Servén (2004).

\subsection{Improving China's current land system: the optimal land supply mode}

The above analysis shows that public land ownership system is more conducive to China's economic development than nonpublic land ownership system, but this does not mean that the current land policy is optimal. The following part will discuss the optimal land policy design under the public land ownership system.

We ran the following numerical simulation on the baseline model: other parameters unchanged, we only changed the supply of "commercial land" (equivalent to changing the equilibrium "commercial land" price) and observed how GDP and other variables change under the steady state. Figure 3 depicts the corresponding relationship between the "commercial land" price and GDP and household welfare level in the steady state in the baseline model under the public land ownership system. The results show that the current supply of "commercial land" is insufficient and its price is too high (three times the cost of
Land system and economic growth

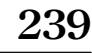


CPE

3,1

\section{0}

Table 4.

Macroeconomics under the nonpublic land ownership system:

raising tax rate to fund infrastructure

construction for growth

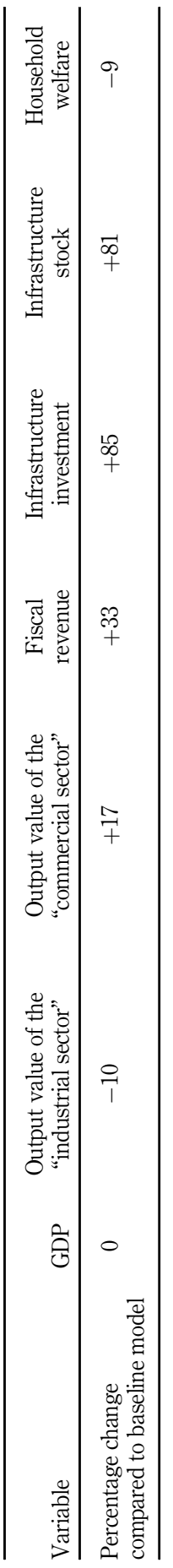




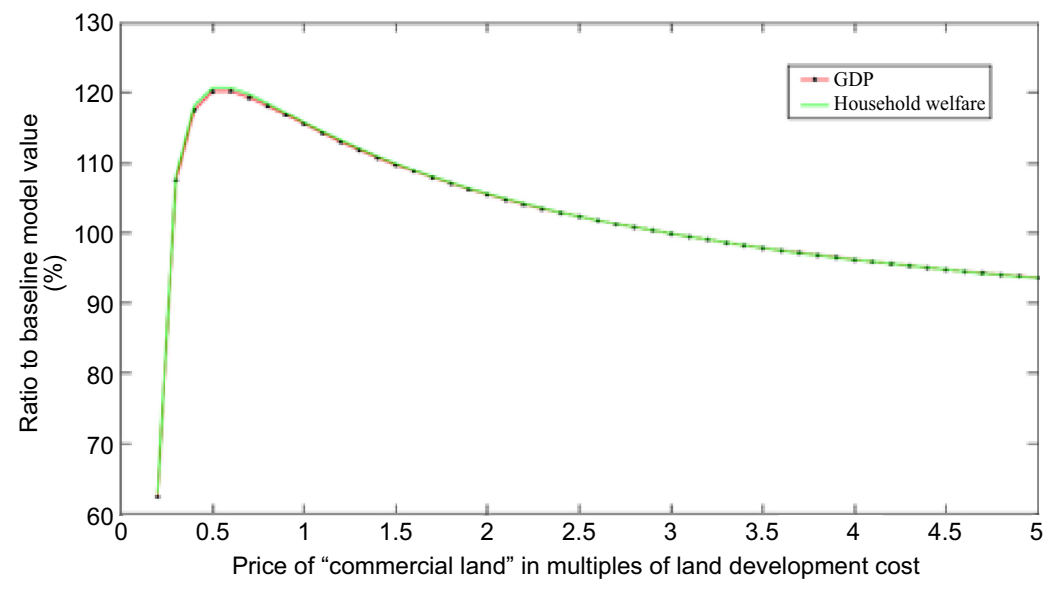

Land system and economic growth

land development). A reduction in the "commercial land" price will help to further improve GDP and household welfare level (per capita consumption level in the steady state) in the long run. The optimal "commercial land" price is about 0.6 times of the cost of land development (meaning that the government provides certain subsidies for "commercial land"), at this time GDP and household welfare level will be increased by about $20 \%$ compared with the baseline model, and the output value of "commercial sector" will be increased by more than $40 \%$ compared with the baseline model driven by the decrease of marginal cost. The decline in the "commercial land" price will not significantly weaken the government's financial capacity, as the increase in tax revenue brought by economic growth will make up for the decline in land rent: at the optimal "commercial land" price, the government's financial revenue has increased by $13 \%$, while the relative proportion of infrastructure investment in GDP is about $7.5 \%$, and there has been no significant decline.

The conclusion of paper on the current excessive cost of "commercial land" price is similar to other studies, which is also in line with the actual situation. The current land supply structure distorts China's real economy. The limited supply of commercial and residential land and high land prices have pushed up house prices, rents and commercial operating costs, inhibiting the development of residents' consumption ability and related service industries, thus inhibiting China's economic growth (Chen and Qiu, 2011; Chen and Liu, 2017; China's Economic Growth Frontier Research Group, 2011; Lu et al., 2015).

Thus, expanding the supply of commercial and residential land and reducing the cost of land in the service sector can promote better economic development from the following aspects. First of all, it will promote the overall economic growth by promoting the development of the service industry, thus improving the overall consumption and welfare level of residents. Secondly, it will lead to tax increases brought about by economic growth replacing "land-based public finance" at the macro level, thus curbing the tendency of "high leverage" of local governments and reducing debt risks. The numerical simulation in this paper shows that from a macro perspective, "land-based public finance" that relies on hefty land transfer fees to finance infrastructure is not necessary. Although expanding the supply of commercial and residential land and reducing the cost of related land factors will greatly reduce the income of land transfer fees, it will promote economic growth and thus lead to the increase of other tax revenues, thus increasing the overall government income level. The debt risk of local government is closely related to "land-based public finance" (Yang et al., 2018). The above adjustment of land supply mode can reduce the dependence of local government 
CPE 3,1

242

on land transfer income, thus resolving the "high leverage" problem of local government caused by "land-based public finance". Moreover, the above adjustment of land supply mode can also improve the aggregate demand structure and cut inefficient investment, thus improving the overall efficiency of the economy.

The relation between adjustment of land supply and optimization of aggregate demand structure can also be analyzed through numerical simulation. Previous studies have pointed out that China's macro-economic aggregate demand structure is unbalanced to a certain extent, with a high investment rate and a low household consumption rate, and the investment-consumption structure deviates from the optimal value (Huang and Wang, 2010; Chen et al., 2014). This paper also supports this conclusion with its analysis. The numerical simulation results show that expanding the supply of commercial and residential land and reducing the cost of land factors in the service sector promote overall economic growth and improve the welfare of residents, and the increase of residents' consumption is larger than that of enterprise and infrastructure investment. In other words, the current aggregate demand structure is unbalanced, and improving the land supply mode can improve the aggregate demand structure, so that investment does not need to increase too much to drive a larger increase in consumption.

That said, Figure 3 also shows that lowering the "commercial land" price to a very low level is not a reasonable policy choice. On the one hand, this will lead to a rapid decline in the marginal output of land; on the other hand, it will greatly weaken the government's financial capacity and affect infrastructure investment, thus causing a significant decline in GDP and household welfare level.

If the land policy is simply abstracted as a price combination of "industrial land" and "commercial land", then the optimal land policy can be defined as the price combination of "industrial land" and "commercial land" that reaches the highest steady-state GDP level. Figure 4 shows the numerical simulation results that can help determine the optimal land policy: under the public land ownership system, the steady-state GDP of different land policies (i.e. "industrial land" and "commercial land" price combinations). Figure 3 is the crosssectional curve of Figure 4, where the "industrial land" price is 1.2 times the land development cost. The results show that when the price combination of "industrial land" and "commercial land" are 0.9 times the land development cost and 0.6 times the land development cost, the GDP level reaches the maximum, and the household welfare level at this time is also the maximum, which is slightly larger than the maximum in Figure 3. Therefore, the current policy of providing "industrial land" at a price close to the cost of land development is close to

Figure 4 .

Impact of different land policies on GDP under public land ownership system

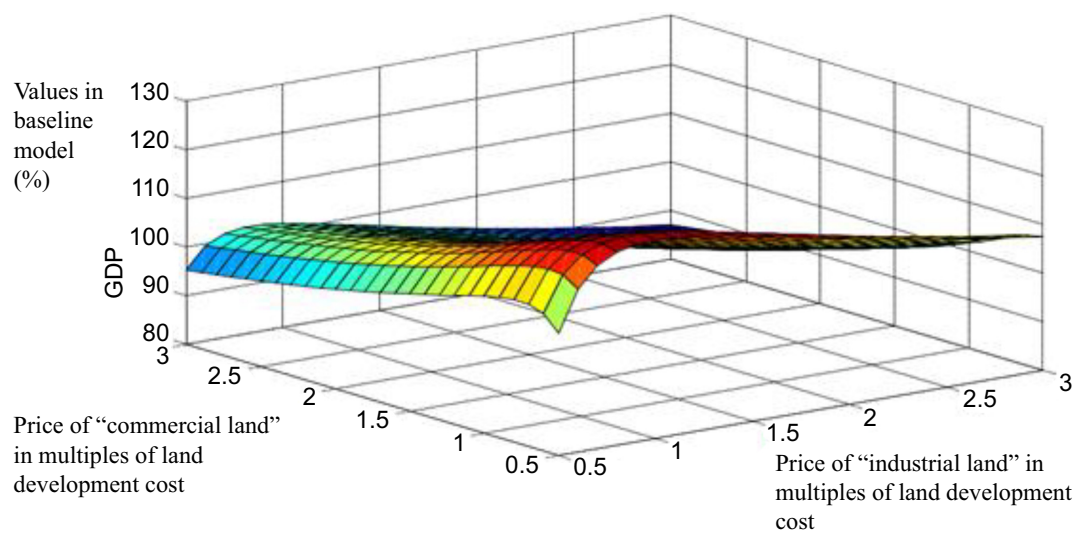


the optimal land policy, which is conducive to promoting the development of the "industrial sector" and the overall economy. However, the "commercial land" price is indeed too high, insufficient in supply and far from the optimal policy. Therefore, consistent with the conclusion in Figure 3, the current land policy is not optimal, and the "commercial land" price needs to be reduced.

In the baseline model, the ratio of "industrial sector" to "commercial sector" is 3:2, which is the average value of the ratio of added value of China's secondary industry and tertiary industry from 1992 to 2015. In the process of industrialization in the past few decades, the industrial sector accounted for a high proportion, while the nonindustrial sector accounted for a relatively low proportion. A logical conjecture is that as China's industrialization comes to an end and the share of nonindustrial sectors continues to increase, the distortion of the real economy by the current land policy will become more and more serious. Data show that the proportion of added value in the secondary industry has dropped from nearly 65\% in 1992 to about $40 \%$ in 2015 . Therefore, we will gradually adjust the parameters reflecting the relative scale of nonindustrial sectors from the benchmark calibration value of $0.4-0.7$, and then recalculate the steady state of the model and compare it with the baseline model.

Figure 5 depicts the relation among the parameters under the current land supply mode (low-price "industrial land" and high-price "commercial land"), the steady state GDP and household welfare level. Just as we predicted, as the proportion of the industrial sector continues to decline, the distortion of the real economy by the current land policy will become more and more obvious. When the proportion of the "industrial sector" in the baseline model falls from $60 \%$ to $40 \%$, if the current land policy is not adjusted, then the steady-state GDP will be reduced to less than $88 \%$ of the baseline model value, and the household welfare level will also decline by almost the same proportion. When the proportion of "industrial sector" is further reduced to $30 \%$, the GDP level will be only about $75 \%$ of the baseline model value.

Therefore, with the relative scale of "industrial sector" shrinking and that of the "commercial sector" expanding, it is more pressing to speed up the adjustment of the current land policy. The key to the adjustment is to increase the supply of "commercial land" and reduce the cost of land for the "commercial sector". Through numerical simulation, we discovered that as the proportion of "commercial goods" in total demand rises to $60 \%$, the optimal price combination of "industrial land" and "commercial land" is 1.0 times the land development cost and 0.6 times the land development cost, respectively. Under such land policy, GDP and household welfare level will reach the maximum, and compared with the baseline model, the steady-state GDP will increase by $12 \%$. When the relative proportion of the "industrial sector" drops to $40 \%$, the current land policy will reduce the steady-state GDP
Land system and economic growth

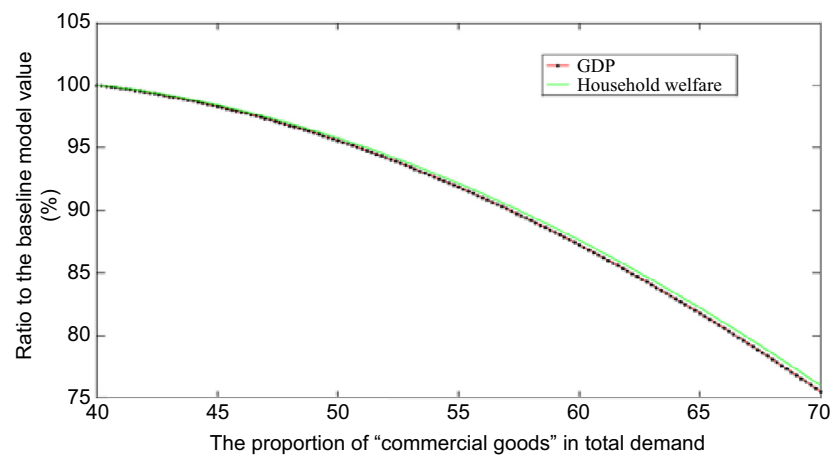

Figure 5. Correlation among the proportion of "commercial goods" in total demand, GDP and household welfare under the current land supply mode 
CPE 3,1

\section{4}

Figure 6.

Correlation among output elasticity of infrastructure, GDP and household welfare under current land supply mode by about $12 \%$; if the and policy is adjusted to reach its optimum (the "commercial land" price needs to be greatly reduced), the steady-state GDP will increase by about $12 \%$.

Another issue worthy of attention is that as China's infrastructure becomes more and more well-developed, the output elasticity of infrastructure may decrease in the future. In fact, some studies believe that some western provinces of China have already seen excessive investment in infrastructure (Shi and Huang, 2014). We analyzed how the steady-state GDP and household welfare level will change and how can land policy respond to the change, if the output elasticity parameter of infrastructure $\alpha_{1}$ and $\alpha_{2}$ are reduced from the baseline model value of 0.2 to 0.1 . Figure 6 shows that steady GDP and household welfare level are positively correlated with the output elasticity of infrastructure. When the output elasticity of infrastructure is reduced from 0.2 to $0.1, \mathrm{GDP}$ and household welfare level will be reduced by about 16\% compared with the baseline model under the current land policy. Further simulation analysis shows that adjusting the current land supply mode, especially lowering the "commercial land" price, can effectively relieve the pressure on economic growth brought by the elastic decline of infrastructure output; At the optimal land policy, the steady-state GDP level will increase by $7.5 \%$ over the baseline model.

In order to test whether the conclusions of this paper on the comparison of economic growth between public and nonpublic land ownership systems and the optimal land policy are stable and reliable, we have carried out a robustness analysis on the parameter calibration of the baseline model and model assumptions. Please refer to the Appendix for relevant analysis. The results show that the main conclusions of this paper are robust. Specifically, we examined 10 cases of parameter calibration that deviated from the baseline model and two cases of where the degree of private land monopoly under the nonpublic land ownership system was lowered. Under these 12 circumstances, the counterfactual analysis results of the nonpublic land ownership system in this paper are very stable: the nonpublic land ownership system is not conducive to China's economic growth. Under the nonpublic land ownership system, high land price will increase the production cost of the industrial sector, while the lack of infrastructure will further lower private investment and economic growth, resulting in a sharp drop in total output and household welfare. In addition, the conclusion on the optimal land supply mode is also stable: the current land supply mode is not optimal, especially in that the supply of the "commercial land" is insufficient and its price is too high; as the proportion of the service sector in China's economy increases, the importance of infrastructure is likely to decline, and the current land supply mode will have a more serious distorting effect on economic growth. Therefore, China should reduce the price of land in nonindustrial sectors to promote better economic development.

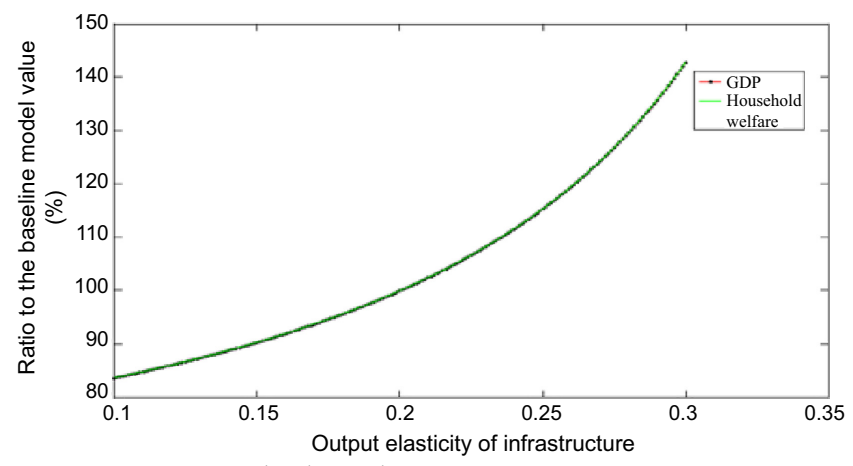

Source(s): Drawn up by the Author 


\section{Summary}

The land system with Chinese characteristics is an important factor to explain China's high economic growth, and the adjustment of land supply mode is also closely related to future economic development. The analysis of this paper showed that: under the nonpublic land ownership system, high land price will increase the production cost of the industrial sector, which, coupled with the lack of infrastructure, will greatly inhibit the enterprise investment and economic growth, thus greatly reducing the total output and household welfare. There are two core reasons that public land ownership system is more conducive to economic growth and household welfare than nonpublic land ownership system. First, the factor of land tends to form a monopoly market, and monopoly will generally lead to distortion of efficiency. The degree of an industrial land market monopoly under the nonpublic land ownership system will increase, resulting in greater distortion of efficiency and household welfare. Second, infrastructure, a public good, plays an important role in economic growth. When land rent flows to the government, the government can use it for infrastructure investment.

Further numerical simulation analysis shows that the current land supply mode is not optimal and the "land-based public finance" is not a necessary solution. With the proportion of the industrial sector in China's economy reduced and the elasticity of infrastructure output in decline, the current land supply model will have an increasingly obvious effect on economic growth. China should expand the supply of commercial and residential land and reduce the price of land in service sectors including real estate.

The policy recommendations in this paper are clear; on the one hand, the public land ownership system is China's institutional advantage, therefore a nonpublic land ownership system is not recommended; On the other hand, the institutional advantages of the current public land ownership system have not been brought into full play. The adjustment of the land supply mode with the expansion of commercial and residential land supply should become an important part of the structural reform on the supply side. From a realistic point of view, real estate bubble in the first and second tier cities is obvious. High housing prices have seriously distorted the investment behavior of enterprises, while the rapid rise in production cost and urban living cost caused by the rapid rise in land price have also greatly hindered the urbanization of the population and the development of service industries. Therefore, the comprehensive expansion of commercial and residential land supply and the reduction of commercial and residential land prices are crucial to the establishment of a long-term mechanism for real estate and the further development of population urbanization and service industry [13]. Getting rid of "land-based public finance" can not only resolve real estate risks and local debt risks but also allow land resources to better serve high-quality development.

That said, some of the conclusions and policy recommendations of this article are based on the analysis of a long-term economic growth. When implementing these policy recommendations, it is necessary to ensure a smooth transition of the economy through some policy measures in the short term. Taking "land-based public finance" as an example, the rise and development of "landbased public finance" has its historical reasons. A comprehensive reduction in the price of commercial and residential land may have a certain impact on local finance in the short term. Therefore, a smooth transition can be achieved through some specific financial system reform measures, such as centralize the decision-making of part of infrastructure construction, education and other matters to the central government, so as to gradually realize a better match of central and local governmental and financial powers. In addition, when formulating specific policies to expand the supply of commercial and residential land, it is also necessary to prevent market players from hoarding land and real estate properties and to discourage speculation, so as to make sure that the fundamental starting point for policy formulation is the effective reduction of land cost.

Land system and economic growth 
CPE 3,1
The model in this paper can be expanded in many aspects to further study on the impact of land system on China's economic growth and structural transformation. First, the model in this paper is a closed economy model, which can be used to build an open economy model. In this way, another channel for public land ownership system to promote China's economic growth can be elaborated: manufacturing enterprises obtain land at a cheap price, which lowers the marginal cost of China's manufacturing products and enhances its international competitiveness, which in turn is conducive to the expansion of exports and production scale. Second, the labor market is also very important. Introducing the labor market into the baseline model of this paper can depict the distortion of the real economy caused by the higher "commercial land" price through the living cost and labor market. Third, in order to simplify the model, we used relatively exogenous government financial behavior (expenditure and tax) in this paper, and more detailed results may be obtained by internalizing the government behavior. Fourth, the industrial structure in this model is exogenous, and the land system with Chinese characteristics may have an impact on the dynamic changes of China's industrial structure. This is also a very interesting issue worth studying, but a more complex macro model of structural changes is needed. We will analyze these issues in future in-depth research.

\section{Notes}

1. Deininger (2003) analyzed international data and pointed out that the degree of land concentration in a country may be negatively related to its economic growth.

2. The study this issue, we can either carry out empirical research based on international data, or theoretical research based on theoretical model and counterfactual analysis. This article falls into the second category.

3. Colonial countries are generally vast and sparsely populated, with relatively abundant land resources.

4. Relevant news reports are available at http://China.cnr.cn/ygxw/20170717/t20170717_523853494.shtml.

5. As mentioned earlier, the labor factor is not considered in the production function in order to simplify the model and analysis in this paper. In fact, such treatment is equivalent to regarding labor supply as fixed and the labor income is included in the production profits.

6. It can also be assumed here that each intermediate product sector has a monopolistic competitive market structure, and that the products produced by numerous small manufacturers in a monopolistic competitive relationship (which can be assumed as constant elasticity of substitution) are finally aggregated into the intermediate products of the sector. Under such assumptions, the main conclusions of this paper remain unchanged.

7. Some literature on infrastructure maintain that infrastructure itself can directly benefit residents. This paper adopts the research paradigm of mainstream literature, and instead of making such assumption, it believes that infrastructure will ultimately affect distribution and residents' consumption by influencing the production of various sectors, thus indirectly affecting household welfare.

8. If $P_{L}^{1}$ is set at 0.05 , that is, assuming the government will sell "industrial land" at the land development cost, the following results will remain mostly unchanged.

9. As discussed below, we will examine the situation where the tax rate can be adjusted by the government, where tax distortion will appear. In addition, this paper assumes that government expenditure $g$ is a relatively exogenous (stable) variable in the long run, so we do not consider the situation where government finances infrastructure by reducing general government expenditure.

10. In this model, the household welfare is defined as the per capita consumption level in the steady state. Of course, it can also be defined as the utility level of residents in the steady state, but this needs a specific form of utility function. Since the utility function is monotonically increasing, so no matter what form of utility function is adopted, the conclusion on welfare in this paper holds true in the qualitative level. 
11. In the baseline model, rent income has become an important source of financing for infrastructure, a special public good, which is related to the Henry George Theorem (Arnott and Stiglitz, 1979). Henry George Theorem states that under certain conditions, government rent income can be used as the only source of funds for public goods, and there is no need for the government to levy other distortionary taxes.

12. From an empirical perspective, in reality, there may be inefficiency in the use of land and infrastructure construction, and the model of this paper does not consider such inefficiencies. However, we believe that this will not affect the main conclusions of this paper. This is because when we conduct counterfactual analysis, we are comparing China with other developing countries that have adopted different land systems, and inefficient use of factors of production and infrastructure construction are also common in other developing countries.

13. Specifically, the government can start from the following aspects: first, speed up the conversion of inefficient and idle industrial land into commercial and residential land in first-tier and some secondtier cities; Second is to accelerate the market access of rural collective construction land. Third is to re-adopt the policy of inter-provincial land exchange for occupation and compensation balance in case of cultivated lands utilization for construction projects; Carry out coordinated management of rural and urban land, linking the increase with reduction in urban and rural construction land. Fourth, increase the floor area ratio of buildings; Fifth is to adopt the highest price limit on the selling price of residential land to benefit the people.

\section{References}

Agenor, P.R. (2010), “A theory of infrastructure-led development”, Journal of Economic Dynamics and Control, Vol. 34, pp. 932-950.

Arnott, R.J. and Stiglitz, J.E. (1979), “Aggregate land rents, expenditure on public goods, and optimal city size", Quarterly Journal of Economics, Vol. 4, pp. 471-500.

Calderón, C. and Servén, L. (2004), "The effects of infrastructure development on growth and income distribution”, The World Bank Policy Research Working Paper Series.

Chen, Y. and Liu, Z. (2017), "Is driving asset prices up able to 'stabilize economic growth'?", Economic Research Journal, Vol. 7, pp. 49-64.

Chen, Y. and Qiu, Z. (2011), "How does housing price affect household saving rate and wealth inequality?", Economic Research Journal, Vol. 10, pp. 25-38.

Chen, Q., Funke, M. and Paetz, M. (2012), "Market and non-market monetary policy tools in a calibrated DSGE model for mainland China”, BOFIT Discussion Paper.

Chen, Y., Chen, X. and Chen, W. (2014), "Interest rate control and imbalance of aggregate demand structure", Economic Research Journal, Vol. 2, pp. 18-31.

Chen, H. (2004), "International comparison and reference of land requisition compensation system", World Agriculture, Vol. 8, pp. 13-15.

China's Economic Growth Frontier Research Group (2011), "Urbanization, fiscal expansion and economic growth", Economic Research Journal, Vol. 11, pp. 4-20.

Deininger, K. (2003), "Land policies for growth and poverty reduction”, World Bank Policy Research Report[C], World Bank, Washington DC.

Du, X., Huang, Zh. and Wu, C. (2009), "Land-based public finance and economic growth in China-an analysis based on provincial panel data", Finance and Trade Economics, Vol. 1, pp. 60-64.

Fernald, J. (1999), "Roads to prosperity? Assessing the link between public capital and productivity", American Economic Review, Vol. 89 No. 3, pp. 619-638.

$\mathrm{Fu}$, Q. and Qiao, Y. (2011), "How government competition promotes China's rapid economic growth: a further discussion on the relation between market segmentation and economic growth", The Journal of World Economy, Vol. 7, pp. 43-63. 
CPE 3,1

Fu, M., Zhang, P. and Yuan, F. (2017), "Evolution of fiscal and tax system in the process of industrialization and urbanization: facts, logic and policy choice", Economic Research Journal, Vol. 12, pp. 29-45.

Ge, Y. and Cen, S. (2017), "Land contributions to the supernormal development of infrastructure in China”, Economic Research Journal, Vol. 2, pp. 35-51.

Gong, L. and Xie, D. (2004), "A factor mobility and dispersion in marginal products: a case on China", Economic Research Journal, Vol. 1, pp. 45-53.

Guo, K., Yu, J. and Gong, L. (2013), "Population policy, labor force structure and economic growth", The Journal of World Economy, Vol. 11, pp. 72-92.

Guo, S., Liu, L. and Zhao, Y. (2015), "The business cycle implications of land financing in China", Economic Modelling, Vol. 46, pp. 225-237.

He, D., Zhang, W. and Shek, J. (2007), "How efficient has been China's investment? Empirical evidence from national and provincial data", Pacific Economic Review, Vol. 12 No. 5, pp. 597-617.

He, X. (2017), "On the advantages of rural land collective ownership", Journal of Nanjing Agricultural University (Social Science), Vol. 3, pp. 1-8.

Huang, Y. and Wang, B. (2010), "Cost distortions and structural imbalances in China”, Journal of World Economy, Vol. 18 No. 4, pp. 1-17.

Jia, J. and Guo, Q. (2011), "Traditional cultural belief, social security and economic growth", The Journal of World Economy, Vol. 8, pp. 3-18.

Jiang, S., Liu, S. and Li, Q. (2007), "Land system reform and national economic growth", Management World, Vol. 9, pp. 1-9.

Jin, G. (2012), "The estimation of China's infrastructure capital stock", Economic Research Journal, Vol. 4, pp. 4-14.

Kang, J., Zhang, Z. and Fu, Y. (2007), “China's economic transformation and growth”, Management World, Vol. 1, pp. 7-17.

Lee, S. and Malin, B.A. (2013), "Education's role in China's structural transformation", Journal of Development of Economics, Vol. 101 No. 1, pp. 148-166.

Lei, X. and Gong, L. (2014), "Industrialization and urbanization based on land transfer", Management World, Vol. 9, pp. 29-41.

Liang, Y. and Dong, M. (2015), "Sources of China's economic growth: analysis based on nonparametric accounting method", The Journal of World Economy, Vol. 11, pp. 29-52.

Liao, P. (2013), "The one-child policy: a macroeconomic analysis", Journal of Development of Economics, Vol. 101 No. 1, pp. 49-62.

Lu, M., Zhang, H. and Liang, W. (2015), "How the bias toward central/western land supplies boosts wages in the east", Social Sciences in China, No. 5, pp. 59-83.

Ma, S. (2013), "International comparison and reference of land development right system", Journal of Dalian University, Vol. 1, pp. 53-57.

Mei, D., Cui, X. and Wu, Y. (2018), "House price fluctuation, land-based public finance and business cycle in China", Economic Research Journal, Vol. 1, pp. 35-49.

Niu, R. and Ding, B. (1990), "International comparison of land system”, Reform, Vol. 6, pp. 127-133.

Shi, H. and Huang, S. (2014), "How much infrastructure is too much? A new approach and evidence from China”, World Development, Vol. 56, pp. 272-286.

Song, Z., Storesletten, K. and Zilibotti, F. (2009), "Growing like China”, American Economic Review, Vol. 101, pp. 196-233.

Sun, X. and Zhou, F. (2013), "Land-based public finance and the tax-sharing system: an empirical explanation", Social Sciences in China, No. 3, pp. 40-59.

Swinnen, J., Herck, K.V. and Vranken, L. (2016), "The diversity of land markets and regulations in europe, and (some of) its causes", Journal of Development Studies, Vol. 52 No. 2, pp. 186-205. 
Van der Ploeg, J.D., Franco, J.C. and Borras, S.M. (2015), "Land concentration and land grabbing in europe: a preliminary analysis", Canadian Journal of Development Studies, Vol. 36 No. 2, pp. 147-162.

World Bank (1994), World Development Report 1994: Infrastructure for Development, China Financial and Economic Publishing House, Beijing.

World Bank (2006), World Development Report 2006, Tsinghua University Publishing House, Beijing.

Wu, Q, Li, Y. and Yan, S. (2015), “The incentives of China's urban land-based public finance”, Land Use Policy, Vol. 42, pp. 432-442.

Xie, D. and Li, R. (2012), "Entrepreneur talent allocation and differences in land concentration effect-A comparison between China and Britain in the 18th and 19th centuries", Journal of Capital University of Economics and Business, Vol. 3, pp. 79-86.

$\mathrm{Xu}, \mathrm{S}$., Chen, J. and Zhao, G. (2018), "How does the land leasing marketization affect the economic growth", China Industrial Economics, Vol. 3, pp. 44-61.

Yang, J., Yang, Q. and Liu, K. (2018), "Land-based public finance and debt growth: an empirical study based on prefecture-level panel data", Finance and Trade Economics, No. 2, pp. 52-68.

Yao, G. and Liu, S. (2015), "A comparative study of land systems between China and India”, World Regional Studies, No. 2, pp. 59-67.

Zhang, J., Wu, G. and Zhang, J. (2004), "Estimation of China's provincial capital stock: 1952-2000", Economic Research Journal, Vol. 10, pp. 35-44.

Zhang, J., Gao, Y., Fu, Y. and Zhang, H. (2007), "Why does China have sound infrastructure?", Economic Research Journal, Vol. 2 No. 3, pp. 4-19.

Zhang, L., Wang, X. and Xu, X. (2011), "Fiscal Incentive, Political incentive and local officials' land supply", China Industrial Economics, Vol. 4, pp. 35-43.

Zhao, F., Wang, C. and Gong, L. (2017), "Land-based public finance and Chinese macroeconomic fluctuations", Economic Research Journal, Vol. 12, pp. 46-61.

\section{Appendix}

Analysis not included in the paper.

This appendix includes diagrams that are not included in the paper (Figures A1-A7) and the robustness test.

Diagrams:

Robustness test:

This part will analyze the robustness of the baseline model in terms of parameter calibration and model assumptions, so as to test whether the conclusions of this paper on the comparison of economic growth under public and nonpublic land ownership system and on the optimal land policy are robust and reliable. We have assessed a total of ten cases of parameter calibration that deviated from the baseline model. Case 1 (R1) and Case 2 (R2) re-evaluated the output elasticity of the infrastructure. Jin (2012) and others believed that the output elasticity of China's infrastructure is relatively high, which may be between 0.2 and 0.7 , so $R 1$ assumed it to be 0.3 , which is higher than the baseline model setting of 0.2 . R2, on the other hand, examined the situation where the output elasticity of infrastructure is small (0.1). Case 3 (R3) and Case 4 (R4) examined the output elasticity of non-infrastructure production factors, different from the baseline model's value of 0.5 , they were set at 0.4 and 0.6 , respectively, while the elasticity of substitution parameters of "industrial products" and "commercial products" were reset to 1.67 and 2.5 respectively.

Case 5 (R5), Case 6 (R6) and Case 7 (R7) examined parameters $\rho_{1}$ and $\rho_{2}$, which indicated the relative importunate of land factor in the production of intermediate products, and $\omega_{1}$ and $\omega_{2}$, which reflects the elasticity of substitution between capital and land. R5 assumed that the land factor is not as important to the "industrial sector" compared with the baseline model and therefore has a greater elasticity of substitution, i.e. assuming that: $\rho_{1}=0.3, \omega_{1}=1.5$ and $\rho_{2}=0.4, \omega_{2}=1.5$. Some studies, such as Li et al. (2011), Wang and $\mathrm{Gu}$ (2015), believed that the contribution of land to China's economic growth was much
Land system and economic growth 


\section{CPE 3,1}

Figure A1. Average price of industrial land, and commercial and residential land: 2000 2015 (unit: Yuan/m2)

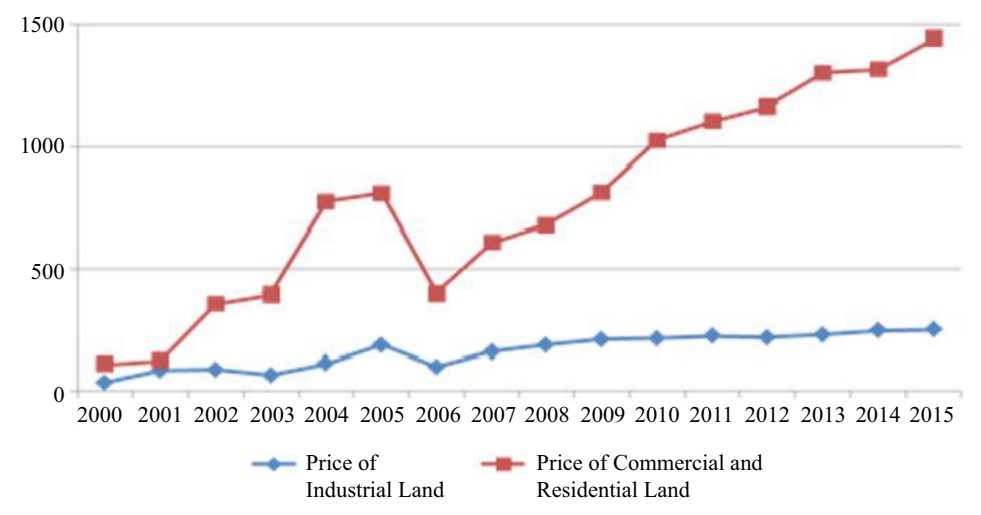

Source(s): Data from Chen et al.(2016), calculated from land transaction data between listed companies and local governments
Figure A2.

Proportion of infrastructure investment to GDP (unit: \%)

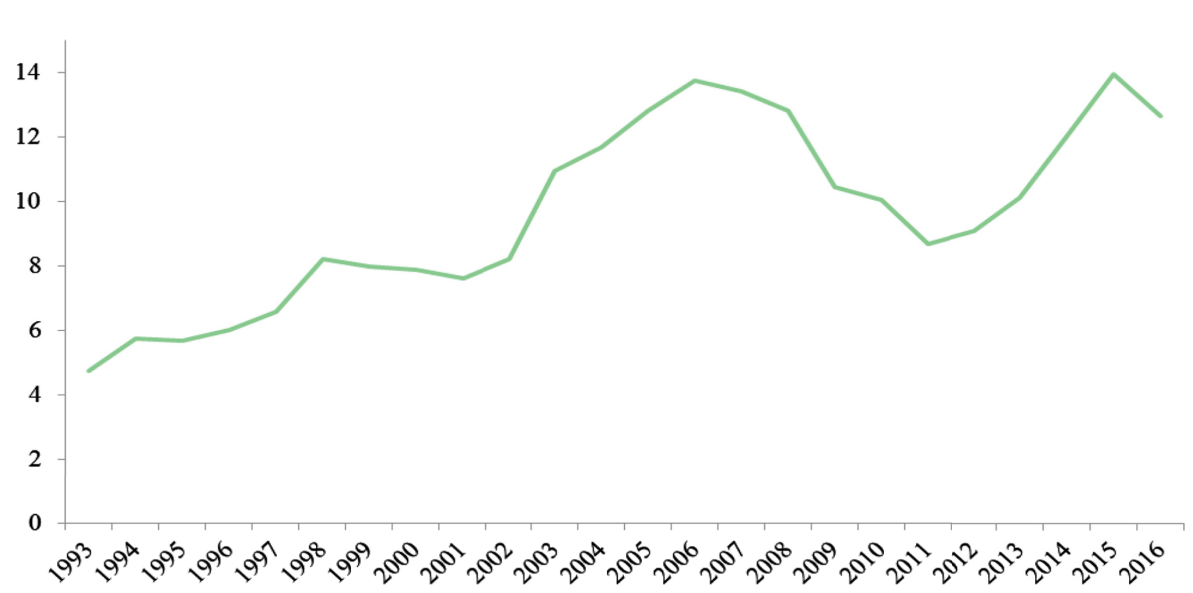

Source(s): The 1993 to 2008 data are calculated by the author using infrastructure data Jin Ge (2012) and GDP data from National Bureau of Statistics of China. The 2009-2016 data are preliminarily calculated by the author using data from National Bureau of Statistics of China on fixed asset investment in infrastructure construction sectors, fixed asset investment delivery and utilization rate and GDP; the infrastructure construction sectors include the following four industries: "electricity, gas and water production and supply", "transportation, storage and postal services", "water conservancy, environment and public facilities management", "information transmission, computer service and software industry", which are consistent with mainstream literature

smaller than that of other factors of production. Therefore, R6 and R7 assumed that the importance of land factor for both "industrial sector" and "commercial sector" decreases. R6 assumes $\rho_{1}=0.3$, $\omega_{1}=1.2, \rho_{2}=0.2$ and $\omega_{2}=1.5$ and R7 assumes $\rho_{1}=0.2, \omega_{1}=1.2, \rho_{2}=0.1$ and $\omega_{2}=2$.

He et al. (2005) and other documents studying China's macro-economy often assume a higher capital depreciation rate than the baseline model, such as $20 \%$ per year. Therefore, scenarios 8 (R8) and 9 (R9) assumed annual depreciation rates to be 15 and $20 \%$, both were higher than that of the baseline model. 


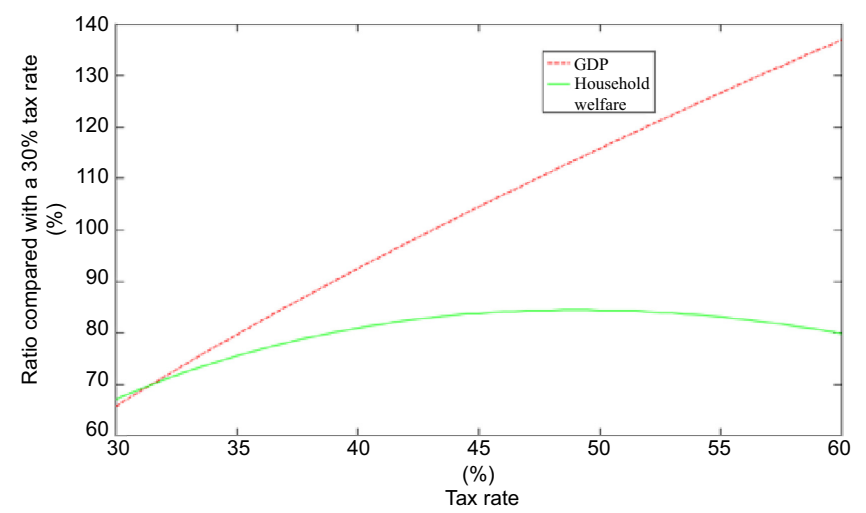

Land system and economic growth

251

Figure A3.

Distortion of

Household welfare Caused by the Policy of Increasing Tax Rate to Promote Growth under Non-public Land Ownership

Source(s): Drawn up by the Author

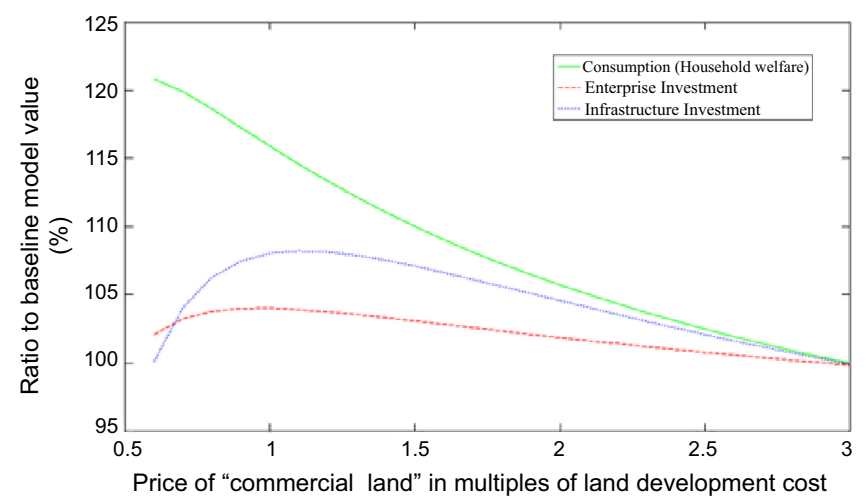

Source(s): Drawn up by the Author

Figure A4.

Adjustment of land supply mode and optimization of aggregate demand structure

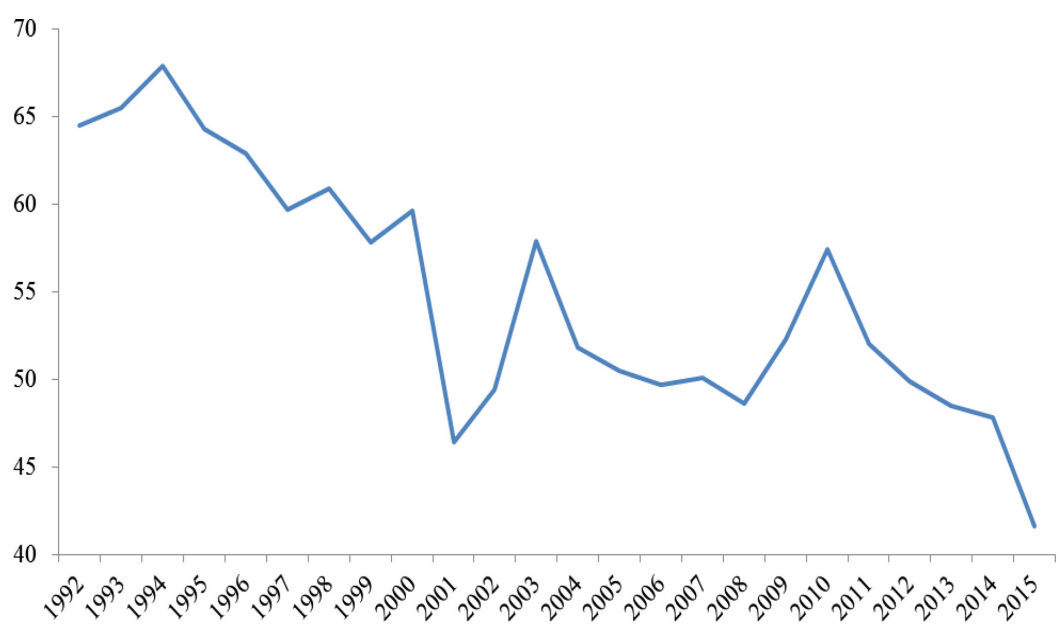

Source(s): National Bureau of Statistics of China

Figure A5.

Proportion of value added of secondary industry to GDP: 1992- 
CPE 3,1

\section{2}

Figure A6.

Impact of different land policies on GDP when the proportion of "commercial goods" in total demand rise to $60 \%$

Figure A7.

Impact of different land policies on GDP when output elasticity of infrastructure declines to 0.1
Case 10(R10) assumed a higher land development $\operatorname{cost} a=0.06$, where the "industrial land" price $P_{L, t}^{1}$ is set at 0.07 , and the supply of "commercial land" $L^{2}$ also needs to be recalibrated so that the "commercial land" price is equal to $\frac{\omega_{2}}{\omega_{2}-1} \cdot a$.

Case 11(R11) and Case 12(R12) relaxed the intensity of land monopoly under the nonpublic land ownership system. Case 11 assumed that the land price is only $60 \%$ of the price determined by Eqns (16) and (17). Case 12 is a further relaxed situation, assuming that the rents of "industrial land" and "commercial land" under the nonpublic land ownership system are only two times the cost of land development.

To test whether the results in Table 3 are stable, Table A1 shows macroeconomic variables such as steady-state GDP, "industrial sector" output value, infrastructure investment, household welfare under the 12 cases in the counterfactual analysis under the non-public land ownership system, compared with baseline model of the public land ownership system. The results show that the counterfactual analysis

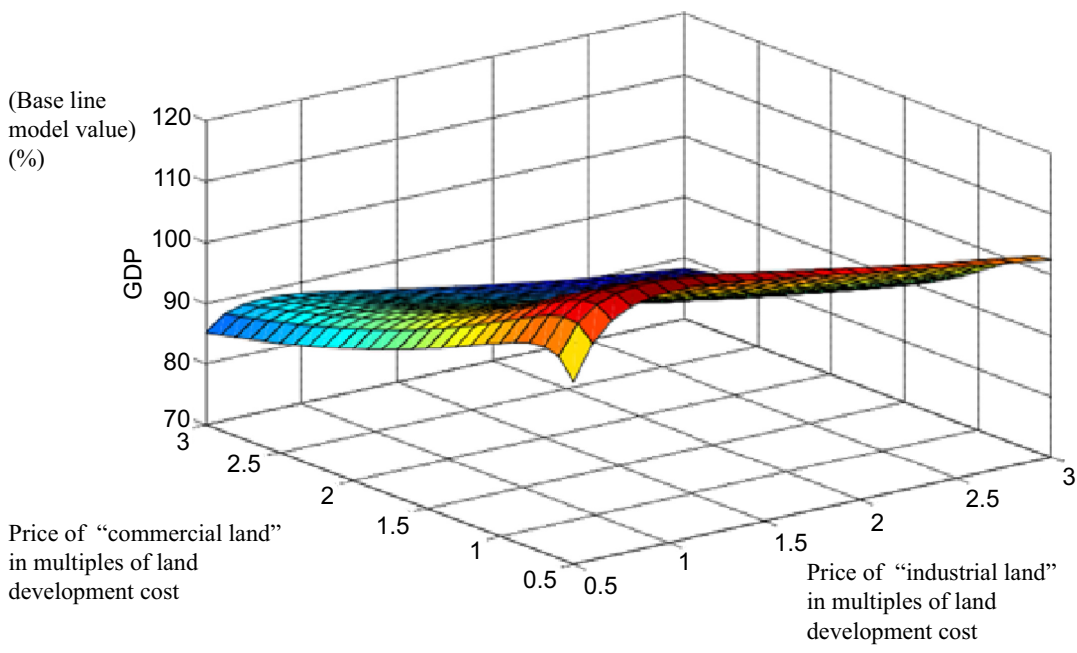

Source(s): Drawn up by the Author

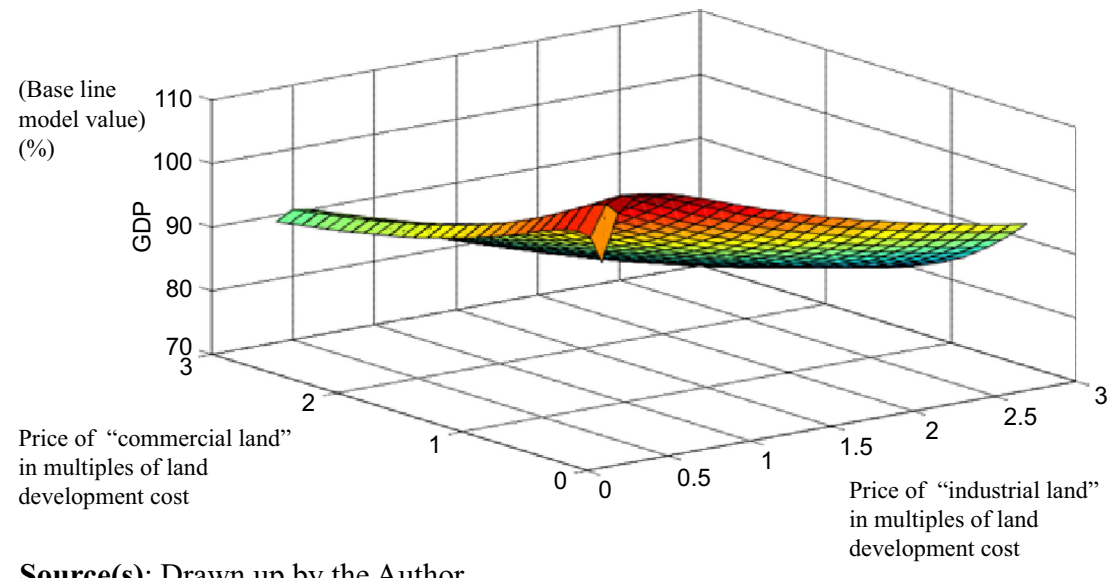

Source(s): Drawn up by the Author 


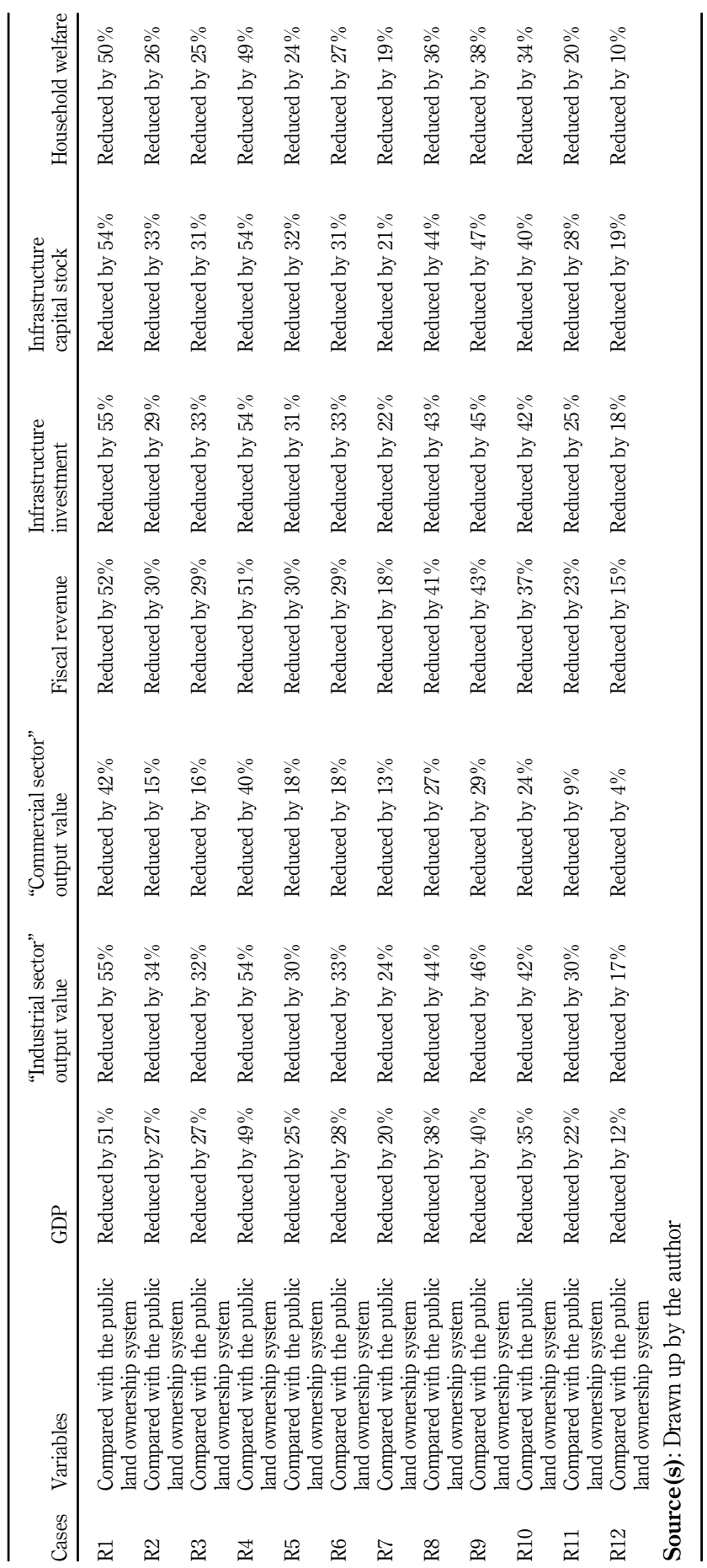

Land system and economic growth

253

Table A1. The macro economy under the nonpublic land ownership system: robustness test of counterfactual analysis 
CPE 3,1 results on the nonpublic land ownership system in this paper is stable: the nonpublic land ownership system is not conducive to China's economic growth. Under the nonpublic land ownership system, high land prices will increase the production cost of the industrial sector, while the lack of infrastructure will further inhibit private investment and economic growth, resulting in a sharp drop in total output and household welfare.

In addition, we also reconducted the numerical simulation of the optimal land policy for the above situations. The results show that the conclusions shown in Figures 3, 5, and 6 and other main conclusions in this paper are stable; although the public land ownership system is more conducive to China's economic growth than the nonpublic land ownership system, the current land supply mode is not optimal, especially in that the supply of "commercial land" is insufficient and its price is too high. With the relative proportion of the industrial sector in China's economy being reduced and the elasticity of infrastructure output likely to decline, the current land supply model will have an increasingly obvious effect on economic growth. China should reduce the price of land in non-industrial sectors to promote better economic development.

\section{References}

Chen, T., Liu, X., Wei, X. and Zhou, L. (2016), “The speculation channel and crowding out channel: real estate shocks and corporate investment in China”, Unpublished manuscript.

He, X., Wu, H., Cao, Y. and Liu, R. (2005), China-QEM, A Quarterly Macro-Econometric Model of China, Social Sciences Academic Press, Beijing.

Li, X., Zhang, R., Ou, M. and Sun, M. (2011), "Study on construction land contribution to secondary and service industry and its spatial correlation”, China Population, Resources and Environment, Vol. 9, pp. 64-68.

Wang J. and Gu G. (2015), "Study on contribution of land element to urban economic growth in China" China Population, Resources and Environment, No. 8, pp. 10-17.

Zhang, J. (2012), “China's infrastructure investment: current situation and the evaluation”, National Development Research Institute of Peking University, "CMRC China Economic Observation” 28th Report [C], Peking University Press, Beijing.

\section{Corresponding author}

Kai Liu can be contacted at: liukeynes@ruc.edu.cn

For instructions on how to order reprints of this article, please visit our website: 